\title{
Evaluación de la estructura comunitaria de las esponjas marinas en parches arrecifales del Caribe sur, Costa Rica
}

\section{Evaluation of the community structure of marine sponges in reef patches of the southern Caribbean, Costa Rica}

\author{
Alexander Araya-Vargas ${ }^{l}$, Linnet Busutill, Andrea Garcia-Rojas ${ }^{2}$, José Miguel Pereira Chaves $^{l}$ y Liliana Piedra-Castro ${ }^{\prime}$ \\ $\begin{array}{lllll}\text { (iD) } 0000-0001-7481-1699 & \text { (D) } 0000-0002-9222-3230 & \text { (D) } 0000-0003-3451-7094 & \text { (D) } 0000-0001-7609-4224 & \text { (D) } 0000-0003-4878-1531\end{array}$
}

1. Escuela de Ciencias Biológicas, Universidad Nacional, Heredia, Costa Rica. alex.araya.vargas@gmail.com*Autor para correspondencia.

2. Departamento de Biología, Instituto de Ciencias del Mar, La Habana, Cuba.

\section{RESUMEN}

$\mathrm{L}$

as esponjas marinas cumplen un gran número de funciones críticas para los arrecifes coralinos. A su vez, las variaciones en la estructura comunitaria de los poríferos pueden indicar cambios en las condiciones ambientales de los ecosistemas donde habitan. Sin embargo, su estudio ha sido escaso en el Caribe de Costa Rica, principalmente en el ámbito ecológico. Por tanto, se evaluó la estructura comunitaria de estos organismos en cuatro parches arrecifales (Perezoso, Pequeño, Coral Garden y el 0,36) y se determinó si podía ser explicada por la sedimentación, el sustrato y la profundidad. Se calculó la abundancia relativa (AR) y la cobertura relativa (CR) para cada especie, la densidad de esponjas e índices de diversidad (riqueza de especies, heterogeneidad de Shannon, equitatividad de Pielou y dominancia de Simpson) para cada sitio de muestreo. Se comparó la similitud entre sitios respecto a las abundancias relativas de esponjas versus sedimentación, sustrato y profundidad. Se encontraron 13 nuevos registros de esponjas para el país. Perezoso presentó la mayor cobertura de esponjas $(\mathrm{CR}=6,1 \%)$ compuesta principalmente por Cliona caribbaea $(\mathrm{CR}=2,0 \%)$ y con Niphates erecta como especie dominante $(\mathrm{AR}=59,3 \%)$. La riqueza de especies aumentó a medida que aumentaba la profundidad en los sitios. Perezoso y Coral Garden mostraron la mayor similitud en cuanto a la abundancia de especies y compartieron a N. erecta, Iotrochota birotulata y Scopalina ruetzleri como las especies más abundantes. Asimismo, compartieron las mayores frecuencias de aparición (40 \%) de esponjas perforadoras del género Siphonodictyon y la presencia de la especie bioerosionadora C. caribbaea. La similitud entre Perezoso y Coral Garden podría estar influenciada en mayor medida por la alta disponibilidad de pavimento calcáreo como sustrato predominante $(48<\mathrm{PC} \%<67)$, el cual parece favorecer la abundancia de esponjas heterotróficas y generalistas, así como la de especies perforadoras y bioerosionadoras.

PALABRAS CLAVE: Porífera, arrecife de coral, sedimentación, sustrato, profundidad.

\section{ABSTRACT}

$\mathrm{M}$ arine sponges fulfill many critical functions to coral reefs. In turn, variations in the community structure of the poriferans may indicate changes in the environmental conditions of the ecosystems where they live. However, their study has been scarce in the Caribbean of Costa Rica, mainly in the ecological field. Therefore, the community structure of these organisms was evaluated in four reef patches (Perezoso, Pequeño, Coral Garden, and the 0.36) and it was determined whether it could be explained by sedimentation, substrate, and depth. Relative abundance (RA) and relative coverage (RC) for each species, sponge density, and diversity indices (species richness, Shannon heterogeneity, Pielou's evenness, and Simpson's dominance) were calculated for each sampling site. Similarity between sites was compared to the relative abundance of sponges versus sedimentation, substrate, and depth. 13 new sponge records were found for the country. Perezoso had the highest sponge coverage $(\mathrm{RC}=6.1 \%)$ composed mainly by Cliona caribbaea $(\mathrm{RC}=2.0 \%)$ and with Niphates erecta as the dominant species $(\mathrm{RA}=59.3 \%)$. Species richness increased as site depth increased. Perezoso and Coral Garden showed the biggest similarity in terms of species abundance and shared $N$. erecta, Iotrochota birotulata and Scopalina ruetzleri as the most abundant species. These sites also shared the highest occurrence frequencies $(40 \%)$ of excavating sponges of the genus Siphonodictyon and the presence of the boring species C. caribbaea. Similarity between Perezoso and Coral Garden could be influenced to a greater extent by the high availability of calcareous pavement as a predominant substrate $(48<\mathrm{PC} \%<67)$, which seems to favor the abundance of heterotrophic and generalist sponges, as well as that of excavating species and boring sponges.

KEYWORDS: Porifera, coral reef, sedimentation, substrate, depth. 


\section{INTRODUCCIÓN}

Las esponjas (filo Porifera) conforman uno de los grupos de animales sésiles más diversos y abundantes de los fondos marinos, y se encuentran en ecosistemas tan importantes y diversos como los manglares, pastos marinos, arrecifes de coral y mar profundo (Díaz, 2012; Cruz-Barraza et al., 2012; Carballo et al., 2014). Para los arrecifes coralinos del mar Caribe se han registrado más de 325 especies de esponjas, y se considera que la diversidad y biomasa de estos organismos en dicho ecosistema puede exceder a la de los corales escleractíneos (orden Scleractinia) y a la de los octocorales (subclase Octocorallia) (Cedro et al., 2007; Cortés et al., 2009; Díaz, 2012). En países de la región caribeña, como Belice, Colombia, Cuba y Panamá, se han desarrollado estudios taxonómicos exhaustivos en arrecifes donde se han registrado más de 90 especies (Rützler et al., 2000; Alcolado, 2002; Díaz, 2005; Valderrama y Zea, 2013).

A su vez, los poríferos cumplen roles fundamentales dentro de los ecosistemas arrecifales. Estos brindan refugio a larvas, juveniles y adultos de muchos otros organismos; filtran grandes volúmenes de agua, por lo que se consideran descontaminadores; constituyen alimento para algunos peces, tortugas (Eretmochelys imbricata) e invertebrados; sirven de sustrato; contribuyen a incorporación de material particulado al fondo; y establecen variadas e importantes relaciones simbióticas con otros organismos. Dado que cumplen tan diversas funciones dentro de los arrecifes y otros ecosistemas, resulta de vital importancia el estudio de sus comunidades (Díaz y Rützler, 2001; Rützler, 2004; Wulff, 2006, 2012; Bell, 2008).

Sin embargo, las investigaciones sobre las esponjas marinas de Costa Rica han sido muy escasas y, específicamente para el Caribe costarricense, solo existen seis trabajos sobre las esponjas del litoral (Risk et al., 1980; Loaiza, 1989, 1991; Cortés, 1996; Van der Hal, 2006; Cortés et al., 2009). Además, no se conocen estudios que aborden aspectos ecológicos o de aprovechamiento de estos organismos en los arrecifes coralinos costarricenses. Entre los trabajos que más han aportado al conocimiento de este grupo en el Caribe del país se encuentran los realizados por Loaiza (1989, 1991), los cuales describen 17 especies de la clase Demospogiae para isla Uvita y Puerto Vargas en el Caribe costarricense. Cortés (1996) registró 38 especies de esponjas marinas para esta región del país a partir de revisiones bibliográficas, identificación de ejemplares preservados en el Museo de Zoología de la Universidad de Costa Rica,

\section{INTRODUCTION}

Sponges (phylum Porifera) makeup one of the most diverse and abundant groups of sessile animals on the seabed and are found in ecosystems as important and diverse as mangroves, seagrasses, coral reefs and the deep sea (Díaz, 2012; Cruz-Barraza et al., 2012; Carballo et al., 2014). For the coral reefs of the Caribbean Sea, more than 325 species of sponges have been registered, and it is considered that the diversity and biomass of these organisms in reef ecosystems may exceed that of scleractinian corals (order Scleractinia) and that of octocorals (subclass Octocorallia) (Cedro et al., 2007; Cortés et al., 2009; Díaz, 2012). In countries of the Caribbean region, such as Belize, Colombia, Cuba and Panama, exhaustive taxonomic studies have been carried out on reefs where more than 90 species have been registered (Rützler et al., 2000; Alcolado, 2002; Díaz, 2005; Valderrama and Zea, 2013).

In turn, poriferans play fundamental roles within reef ecosystems. These provide refuge for larvae, juveniles, and adults of many other organisms; they filter large volumes of water, which is why they are considered decontaminators; they constitute food for some fish, turtles (Eretmochelys imbricata) and invertebrates; they serve as a substrate; contribute to the incorporation of particulate material into the bottom, and they establish varied and important symbiotic relationships with other organisms. Given that they fulfill such diverse functions within reefs and other ecosystems, the study of their communities is vitally important (Díaz and Rützler, 2001; Rützler, 2004; Wulff, 2006, 2012; Bell, 2008).

However, research on sea sponges in Costa Rica has been very scarce and, specifically for the Costa Rican Caribbean, there are only six works on shoreline sponges (Risk et al., 1980; Loaiza, 1989, 1991; Cortés, 1996; Van der Hal, 2006; Cortés et al., 2009). Also, there are no known studies that address ecological aspects or the use of these organisms in coral reefs. Among the works that have contributed the most to the knowledge of this group in the country's Caribbean are those carried out by Loaiza (1989, 1991), which describe 17 species of the Demospogiae class for Uvita island and Puerto Vargas in the Costa Rican Caribbean. Cortés (1996) recorded 38 species of sea sponges for this region of the country from bibliographic reviews, identification of specimens preserved in the Zoology Museum of the University 
consultas a expertos y trabajos en progreso durante ese momento. Por su lado, Van der Hal (2006) ha sido el único en realizar un estudio ecológico sobre esponjas marinas para su tesis, específicamente en los pastos marinos y arrecifes someros (1-4 m) de la costa caribeña. Posteriormente, Cortés et al. (2009) registraron 65 especies para el Caribe costarricense comprendidas en una clase, dos subclases, 10 órdenes, 29 familias y 45 géneros. En dichos estudios, los autores concluyeron sobre la necesidad de realizar más investigaciones, principalmente relacionadas con las especies presentes, su distribución, estado de conservación y ecología.

La poca información ecológica generada para el filo Porifera en Costa Rica ha resultado en el desconocimiento del valor ecológico para el desarrollo de planes de manejo de este grupo, y en el poco aprovechamiento de estos organismos como posible fuente de ingresos económicos para las comunidades costeras. Las esponjas, al ser seres sésiles, filtradoras, de amplia distribución, persistentes en el tiempo, de rápido crecimiento y con tasas de cambio en su cubrimiento del fondo, reflejan las condiciones promedio del ambiente. Por tales motivos, variaciones en su estructura comunitaria pueden indicar cambios en las condiciones ambientales de los ecosistemas donde habitan (Alcolado, 2007). Considerando lo anterior, surge la necesidad de desarrollar un estudio de línea base donde se evalúe la estructura comunitaria de las esponjas marinas en los parches arrecifales del Caribe sur costarricense y se determine si puede ser explicada por la influencia de factores abióticos como la sedimentación, el sustrato y la profundidad. Los resultados de este estudio conformarán un insumo importante para el desarrollo de pautas para la conservación y el uso de las esponjas marinas en el país.

\section{ÁREA DE ESTUDIO}

El Caribe sur costarricense se caracteriza por poseer playas arenosas con algunas protuberancias rocosas de arrecifes de coral fósil, dos islas cerca de la costa con formaciones coralinas, además de sustratos calcáreos, arenosos y sedimentos terrígenos costa afuera (Cortés y Wehrtmann, 2009). El clima es húmedo (70-100 \%) y caluroso, con temperaturas máximas de $32{ }^{\circ} \mathrm{C}$; presenta dos estaciones lluviosas (noviembre a marzo y junio a agosto) con un promedio de $2500 \mathrm{~mm}$ anuales en la parte sur (Cortés y Wehrtmann, 2009; Cortés et al., 2010). Las mareas son de tipo mixto, con diurnas predominantes, las cuales varían entre los 30 y $50 \mathrm{~cm}$ de amplitud (Fonseca, 2003; Cortés y of Costa Rica, consultations with experts, and work in progress during that time. For his part, Van der Hal (2006) has been the only one to carry out an ecological study on sea sponges for his thesis, specifically in seagrasses and shallow reefs (1-4 m) in the Caribbean area. Subsequently, Cortés et al. (2009) recorded 65 species for the Costa Rican Caribbean included in one class, two subclasses, 10 orders, 29 families, and 45 genera. In these studies, the authors concluded on the need for more research, mainly related to the species present, their distribution, conservation status, and ecology.

The little ecological information generated for the Porifera ridge in Costa Rica has resulted in ignorance of the ecological value for the development of management plans for this group, and the little use of these organisms as a possible source of economic income for coastal communities. The sponges, being sessile, filtering beings, of wide distribution, persistent in time, of fast growth and with rates of change in their bottom coverage, reflect the average conditions of the environment. For these reasons, variations in their community structure may indicate changes in the environmental conditions of the ecosystems where they inhabit (Alcolado, 2007). Considering the above, the need arises to develop a baseline study evaluating the community structure of sea sponges in the reef patches of the Costa Rican South Caribbean and determining if it can be explained by the influence of abiotic factors such as sedimentation, substrate, and depth. The results of this study will form an important input for the development of guidelines for the conservation and use of sea sponges in the country.

\section{STUDY AREA}

The Costa Rican South Caribbean is characterized by having sandy beaches with some rocky protrusions of fossil coral reefs, two islands near the coast with coral formations, in addition to calcareous, sandy substrates and terrigenous offshore sediments (Cortés and Wehrtmann, 2009). The climate is humid (70-100 \%) and hot, with maximum temperatures of $32{ }^{\circ} \mathrm{C}$; it presents two rainy seasons (November to March and June to August) with an average of $2500 \mathrm{~mm}$ per year in the southern part (Cortés and Wehrtmann, 2009; Cortés et al., 2010). The tides are of mixed type, with predominant diurnal ones, which vary between 30 and $50 \mathrm{~cm}$ in width (Fonseca, 2003; Cortés and Wehrtmann, 2009; Cortés et al., 2010). Also, the current 
Wehrtmann, 2009; Cortés et al., 2010). Además, la corriente cercana a la costa es fuerte, así como el oleaje que genera; y se mueve de noroeste a sureste (Fonseca, 2003; Cortés et al., 2010).

Los arrecifes de esta región pueden dividirse en dos secciones: los parches de arrecife y bancos carbonatados del Parque Nacional Cahuita, y los arrecifes de franja, parches, crestas algales y bancos carbonatados entre Puerto Viejo y Punta Mona. Dentro de estos arrecifes se han registrado en total 41 especies de corales escleractíneos y 26 de octocorales (Cortés y Jiménez, 2003; Cortés y Wehrtmann, 2009).

Dentro del área descrita, se identificaron y georreferenciaron cuatro parches arrecifales con presencia de esponjas marinas (Tabla 1, Figura 1) mediante premuestreos (febrero-abril de 2015) y consultas a tour-operadores, buzos y pescadores locales con extenso conocimiento del área marina. Estos sitios, además, se caracterizaron por ser importantes para la economía de la zona debido a la actividad pesquera y turística. Dos de los sitios (Pequeño y el 0,36) quedaron ubicados fuera de áreas protegidas, donde no existe un control sobre las actividades que se realizan (Figura 1). near the coast is strong, as well as the waves it generates; and it moves from northwest to southeast (Fonseca, 2003; Cortés et al., 2010).

The reefs of this region can be divided into two sections: the reef patches and carbonate banks of the Cahuita National Park, and the fringe reefs, patches, algal crests and carbonate banks between Puerto Viejo and Punta Mona. A total of 41 species of scleractinian corals and 26 octocorals have been registered within these reefs (Cortés and Jiménez, 2003; Cortés and Wehrtmann, 2009).

Within the described area, four reef patches with the presence of sea sponges were identified and georeferenced (Table 1, Figure 1) through presampling (February-April 2015) and consultations with local tour operators, divers, and fishermen with extensive knowledge of the marine area. These sites, also, were characterized by being important for the economy of the area due to fishing and tourist activity. Two of the sites (Pequeño and 0.36) were located outside of protected areas, where there is no control over the activities carried out (Figure 1).

Tabla 1. Caracterización de los sitios de muestreo

Table 1. Characterization of the sampling sites

\begin{tabular}{|c|c|c|c|c|c|}
\hline Sitio/Site & $\begin{array}{l}\text { Poblado/ } \\
\text { Town }\end{array}$ & $\begin{array}{c}\text { Área protegida/Protected } \\
\text { area }\end{array}$ & $\begin{array}{l}\text { Coordenadas/ } \\
\text { Coordinates }\end{array}$ & $\begin{array}{l}\text { Profundidad } \\
\text { promedio/ } \\
\text { Average depth }\end{array}$ & Descripción/Description \\
\hline $\begin{array}{l}\text { Barrera de } \\
\text { coral Perezoso/ } \\
\text { Perezoso barrier } \\
\text { reef (Perezoso) }\end{array}$ & Cahuita & $\begin{array}{l}\text { Parque Nacional Cahuita/ } \\
\text { Cahuita National Park } \\
\text { (PNC) }\end{array}$ & $\begin{array}{l}9^{\circ} 44^{\prime} 52.476 \text { " N y } \\
82^{\circ} 49^{\prime} 18.624^{\prime \prime} \mathrm{O}\end{array}$ & $6 \mathrm{~m}$ & $\begin{array}{l}\text { Pared externa de la barrera arrecifal con alta } \\
\text { sedimentación y visitación turística/External wall } \\
\text { of the reef barrier with high sedimentation and } \\
\text { tourist visitation. }\end{array}$ \\
\hline Pequeño & Puerto Viejo & Ninguna/None & $\begin{array}{l}9^{\circ} 39^{\prime} 41.112^{\prime \prime} \mathrm{N} \mathrm{y} \\
85^{\circ} 45^{\prime} 17.748^{\prime \prime} \mathrm{O}\end{array}$ & $5 \mathrm{~m}$ & $\begin{array}{l}\text { Parche de arrecife pequeño, aproximadamente } \\
\text { a } 100 \mathrm{~m} \text { de la costa. Gran abundancia de } \\
\text { octocorales/Pequeño reef patch, approximately } \\
100 \mathrm{~m} \text { from the coast. Great abundance of } \\
\text { octocorals. }\end{array}$ \\
\hline Coral Garden & Punta Uva & $\begin{array}{l}\text { Refugio Nacional de } \\
\text { Vida Silvestre Gandoca- } \\
\text { Manzanillo/Gandoca- } \\
\text { Manzanillo National } \\
\text { Wildlife Refuge (REGAMA) }\end{array}$ & $\begin{array}{l}9^{\circ} 39^{\prime} 11.124 \text { " N y } \\
82^{\circ} 41^{\prime} 33.936 \text { " O }\end{array}$ & $18 \mathrm{~m}$ & $\begin{array}{l}\text { Pared carbonatada con alta riqueza de corales. } \\
\text { Utilizada para el buceo recreativo/Carbonate wall } \\
\text { with high coral richness. Used for recreational } \\
\text { diving. }\end{array}$ \\
\hline El 0,36 & Manzanillo & Ninguna/None & $\begin{array}{l}9^{\circ} 39^{\prime} 21.564^{\prime \prime} \mathrm{N} \mathrm{y} \\
82^{\circ} 39^{\prime} 44.64^{\prime \prime} \mathrm{O}\end{array}$ & $8 \mathrm{~m}$ & $\begin{array}{l}\text { Plataforma arrecifal carbonatada cubierta con } \\
\text { arena gruesa. Fuertes corrientes. Importante para } \\
\text { la pesca local/Carbonated reef platform covered } \\
\text { with coarse sand. Strong currents. Important for } \\
\text { local fishing. }\end{array}$ \\
\hline
\end{tabular}




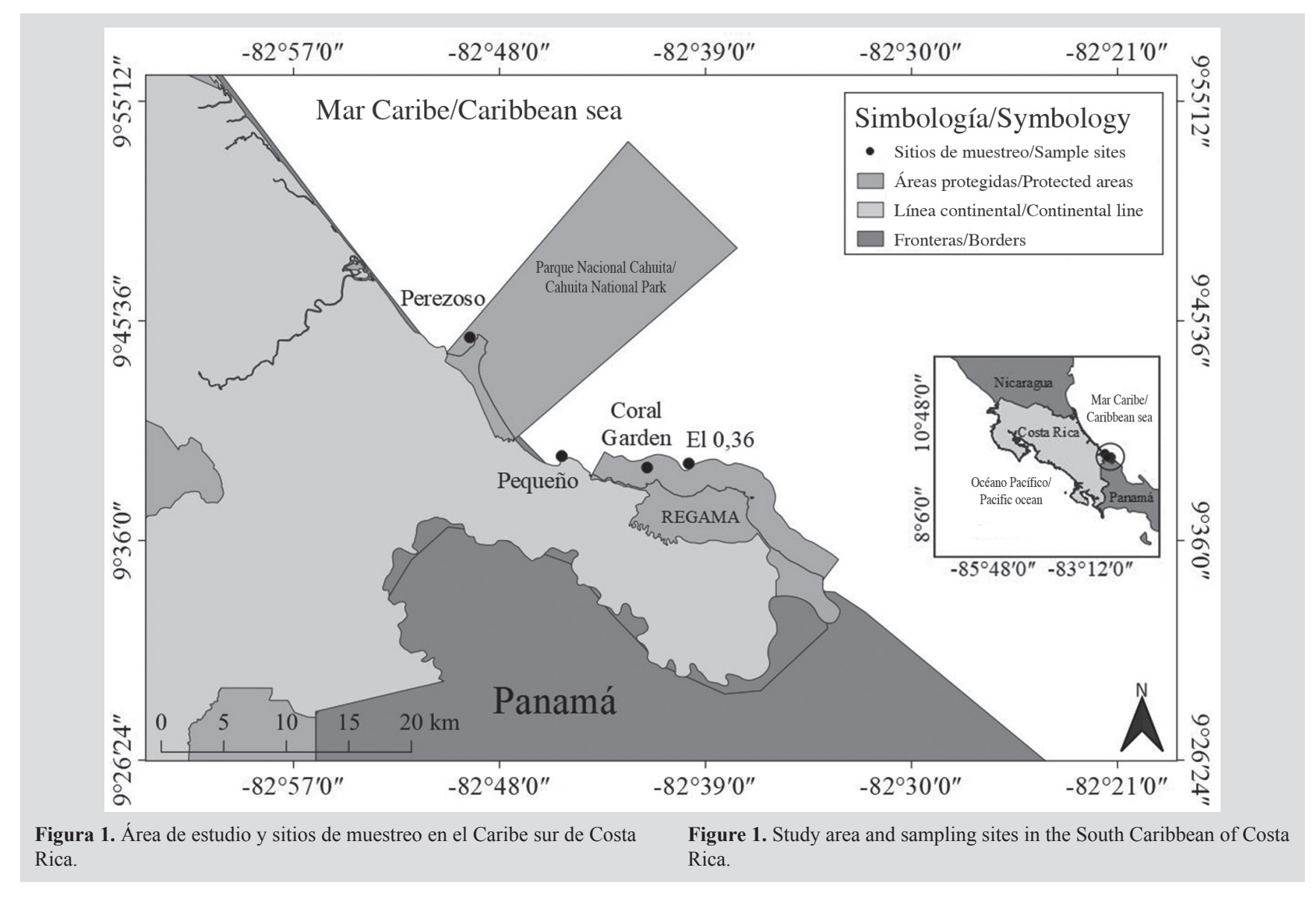

\section{MATERIALES Y MÉTODOS}

Metodología de muestreo y análisis de las muestras

El muestreo se desarrolló con buceo autónomo (SCUBA) en los meses de octubre de 2015 y mayo de 2016, cuando las condiciones oceánicas y atmosféricas del Caribe sur fueron óptimas (i.e. baja precipitación, bajo o nulo oleaje y alta visibilidad). Se realizaron cinco foto-transectos de banda de $10 \mathrm{~m}$ de longitud por $1 \mathrm{~m}$ de ancho en cada uno de los sitios de muestreo, con una cámara subacuática Nikon COOLPIX AW130. Los transectos se establecieron por medio de un diseño aleatorio sistemático basado en la metodología de monitoreo Caricomp (2001). Como unidad de muestreo se utilizó un marco de $1 \mathrm{~m}^{2}$, elaborado con tubos y codos de PVC y con agujeros cada $10 \mathrm{~cm}$ para facilitar su hundimiento en el agua. El marco fue subdividido en un total de 100 cuadrículas de $0,01 \mathrm{~m}^{2}$ utilizando una cuerda delgada, la cual se entrecruzaba entre los agujeros en forma de red (modificado de Weinberg, 1981).

Las fotografías de los marcos de $1 \mathrm{~m}^{2}$ fueron analizadas posteriormente para cuantificar el número de individuos y estimar el porcentaje de cobertura total

\section{MATERIALS AND METHODS}

Sampling methodology and sample analysis

The sampling was carried out with autonomous diving (SCUBA) in October 2015 and May 2016, when the oceanic and atmospheric conditions of the South Caribbean were optimal (i.e. low precipitation, low or no waves, and high visibility). Five $10 \mathrm{~m}$ long by $1 \mathrm{~m}$ wide band phototransects were recorded at each of the sampling sites with a Nikon COOLPIX AW130 underwater camera. The transects were established utilizing a systematic random design based on the CARICOMP (2001) monitoring methodology. A $1 \mathrm{~m}^{2}$ frame was used as the sampling unit, made with PVC tubes and elbows, and with holes every $10 \mathrm{~cm}$ to facilitate its submergence in the water. The frame was subdivided into a total of $1000.01 \mathrm{~m}^{2}$ grids using a thin rope, which intersected between the holes in the form of a network (modified from Weinberg, 1981).

The photographs of the $1 \mathrm{~m}^{2}$ frames were subsequently analyzed to quantify the number of individuals and estimate the percentage of total coverage by sponge species or by type of substrate available, using the $0.01 \mathrm{~m}^{2}$ 
por especie de esponja o por tipo de sustrato disponible, utilizando como referencia las cuadrículas de $0,01 \mathrm{~m}^{2}$ con una precisión de hasta $0,001 \mathrm{~m}^{2}$. El porcentaje de cobertura del sustrato disponible fue clasificado en pavimento calcáreo desnudo, pavimento calcáreo con sedimentos, pavimento calcáreo con arena gruesa y fondo con sedimentos.

Las especies de esponjas fueron identificadas visualmente hasta el taxón más bajo posible utilizando la guía propuesta por Collin et al. (2005) y el sitio web www. spongeguide.org (Zea et al., 2014). Así mismo, se colectaron en bolsas plásticas previamente rotuladas los especímenes que no pudieron ser identificados in situ y se anotaron las siguientes características: forma, color en vivo, consistencia y tipo de superficie; según los criterios de Loaiza (1991). Posteriormente, las muestras de esponjas fueron preservadas en alcohol al 90 \% y llevadas al Laboratorio de Recursos Naturales y Vida Silvestre (LARNAVISI), de la Universidad Nacional de Costa Rica, para su identificación con base en la morfología externa de las esponjas y la morfometría de las espículas, según lo propuesto por Boury-Esnault y Rüztler (1997), Hooper y Van Soest (2002) y Díaz (2005). Para la preparación de las espículas se tomaron al menos tres fragmentos de aproximadamente $2 \mathrm{~cm}^{2}$, correspondientes a distintas partes de la esponja, los cuales se digirieron en hipoclorito de sodio de uso comercial al $3 \%$ por un mínimo de 30 minutos. Seguidamente, las preparaciones fueron observadas al microscopio de luz en portaobjetos para identificar y medir las espículas correspondientes a cada muestra. Las esponjas que no pudieron ser identificadas taxonómicamente se separaron y agruparon según sus características morfológicas externas y sus espículas, y se les asignó un nombre compuesto por la palabra "especie" y un número entero consecutivo.

\section{Determinación de las tasas de sedimentación}

Con el fin de determinar si había alguna relación entre la sedimentación y la abundancia de esponjas, se determinaron las tasas de sedimentación por sitio mediante una modificación a la metodología propuesta por GarzónFerreira et al. (2002). La misma consistió en el uso de dos trampas de sedimento por sitio, colocadas a la profundidad promedio donde se encontraban las esponjas (Tabla 1). Se aseguró que todas las trampas de sedimento se recolectaran transcurrido el mismo número de días, con una duración de al menos un mes, cuando las condiciones oceanográficas así lo permitieran; o en su defecto, en un máximo de cuatro meses.

Los sedimentos se transportaron hacia el LARNAVISI donde se tamizaron con un colador de $1 \mathrm{~mm}$ de ojo de malla. grids as a reference with an accuracy of up to $0.001 \mathrm{~m}^{2}$. The percentage of available substrate coverage was classified into the bare calcareous pavement, calcareous pavement with sediments, calcareous pavement with coarse sand, and bottom with sediments.

Sponge species were visually identified to the lowest possible taxon using the guideline proposed by Collin et al. (2005) and the website www.spongeguide. org (Zea et al., 2014). Likewise, specimens that could not be identified in situ were collected in previously labeled plastic bags and the following characteristics were noted: shape, live color, consistency, and type of surface; according to the criteria of Loaiza (1991). Subsequently, the sponge samples were preserved in $90 \%$ alcohol and taken to the Laboratory of Natural Resources and Wildlife (LARNAVISI), National University of Costa Rica, for identification based on external morphology of the sponges and morphometry of the spicules, as proposed by BouryEsnault and Rüztler (1997), Hooper and Van Soest (2002) and Díaz (2005). For the preparation of the spicules, at least three fragments of approximately $2 \mathrm{~cm}^{2}$ were taken, corresponding to different parts of the sponge, which were digested in $3 \%$ sodium hypochlorite for commercial use for a minimum of 30 minutes. Next, the preparations were observed under a light microscope on slides to identify and measure the spicules corresponding to each sample. Sponges that could not be taxonomically identified were separated and grouped according to their external morphological characteristics and their spicules, and they were assigned a name consisting of the word "species" and a consecutive integer.

\section{Determination of sedimentation rates}

To determine if there was any relationship between sedimentation and sponge abundance, sedimentation rates per site were determined through a modification to the methodology proposed by Garzón-Ferreira et al. (2002). It consisted of the use of two sediment traps per site, placed at the average depth where the sponges were found (Table 1). It was ensured that all the sediment traps were collected after the same number of days, with a duration of at least one month, when oceanographic conditions allowed it; or failing that, in a maximum of four months.

The sediments were transported to LARNAVISI where they were sieved with a $1 \mathrm{~mm}$ mesh eye strainer. Subsequently, the sediments were subjected to two washing sessions by precipitation in freshwater for two days to 
Posteriormente, se sometieron a dos sesiones de lavado por precipitación en agua dulce durante dos días para eliminar su contenido de sal. Seguidamente, se les retiró el agua con ayuda de una manguera de hule, se colocaron en beakers de $100 \mathrm{ml}$ previamente pesados y se secaron en un horno a $90{ }^{\circ} \mathrm{C}$ durante tres días. Finalmente, usando una balanza analítica Setra BL-410S, se determinó el peso seco en gramos. La tasa de sedimentación se calculó a partir de la siguiente ecuación corregida de Garzón-Ferreira et al. (2002):

$$
T F S=\frac{W g(1000 \mathrm{mg})}{1 \mathrm{~g}} \frac{1}{A B} \frac{1}{N D}
$$

Donde,

TFS: tasa de sedimentación por fracción ( $\mathrm{mg} / \mathrm{cm}^{2} /$ día)

$\mathrm{W}$ : peso $(\mathrm{g})$

$\mathrm{AB}$ : área de la boca de la trampa

ND: número de días que la trampa estuvo bajo el mar

Las tasas de sedimentación fueron calculadas considerando el número de días durante los cuales estuvo sumergida la trampa. Esto permitió realizar comparaciones entre las diferentes trampas a pesar de que fueron retiradas tras transcurrir diferentes tiempos: entre uno y cuatro meses.

Procesamiento de los datos

Para cada una de las especies de esponjas por sitio se calculó la abundancia relativa porcentual (AR \%) y se estimó el porcentaje de cobertura relativa (CR \%), así como las densidades (individuos $/ \mathrm{m}^{2}$ ) totales de esponjas por sitio. Además, se calcularon los siguientes índices: riqueza de especies (S), heterogeneidad de Shannon (H') (Shannon, 1948), equitatividad de Pielou (J') (Pielou, 1969) y dominancia de Simpson (D) (Simpson, 1949), para determinar la diversidad de esponjas por sitio. Estos índices fueron seleccionados para cuantificar, interpretar y comparar la diversidad de las comunidades de esponjas de este estudio con la registrada por otros autores en arrecifes caribeños. Asimismo, los valores de estos índices permitirán realizar comparaciones sobre esta misma área en futuras investigaciones, y detectar si ocurrieron cambios en el tiempo. Adicionalmente, se aplicaron los criterios propuestos por Alcolado (1999; 2007) para determinar el grado de severidad y pronosticabilidad ambiental de los sitios. Este método consiste en un diagrama de inferencia obtenido de un gráfico de dispersión de pares de valores H' y J', el cual se subdivide en en 11 zonas o clases de inferencia que reflejan qué tan severas y constantes son las condiciones para las esponjas marinas en el sitio (Alcolado, 2007).

De estos análisis, excepto del índice S, se excluyeron las esponjas del género Siphonodictyon, pues debido a su eliminate their salt content. Subsequently, the water was removed with the help of a rubber hose, they were placed in pre-weighted $100 \mathrm{ml}$ beakers and dried in an oven at $90{ }^{\circ} \mathrm{C}$ for three days. Finally, using a Setra BL-410S analytical balance, the dry weight in grams was determined. The sedimentation rate was calculated from the following corrected equation by Garzón-Ferreira et al. (2002):

$$
T F S=\frac{W g(1000 \mathrm{mg})}{1 \mathrm{~g}} \frac{1}{A B} \frac{1}{N D}
$$

Where,

TFS: sedimentation rate per fraction $\left(\mathrm{mg} / \mathrm{cm}^{2} /\right.$ day $)$

W: weight $(\mathrm{g})$

AB: trap mouth area

ND: number of days the trap was under the sea

Sedimentation rates were calculated considering the number of days during which the trap was submerged. This allowed comparisons to be made between the different traps even though they were removed after different times, between one and four months.

\section{Data processing}

For each of the sponge species per site, the relative percentage abundance (AR \%) was calculated and the relative coverage percentage (CR \%) was estimated; as well as the total densities (individuals $/ \mathrm{m}^{2}$ ) of sponges per site. Also, the following indices were calculated: species richness (S), Shannon heterogeneity (H') (Shannon, 1948), Pielou fairness (J') (Pielou, 1969), and Simpson (D) dominance (Simpson, 1949), to determine sponge diversity by the site. These indices were selected to quantify, interpret, and compare the diversity of the sponge communities in this study with that recorded by other authors in Caribbean reefs. Likewise, the values of these indices will allow comparisons to be made on this same area in future investigations, and to detect if changes occur over time. Additionally, the criteria proposed by Alcolado (1999; 2007) were applied to determine the degree of severity and environmental predictability of the sites. This method consists of an inference diagram obtained from a scatter plot of pairs of H' and J' values, which is subdivided into 11 zones or classes of inference that reflect how severe and constant the conditions are for marine sponges on the site (Alcolado, 2007).

From these analyzes, except for the S index, sponges of the Siphonodictyon genus were excluded, because due to their perforating habit and the development of a large part of their tissues within the substrate they 
hábito perforador y al desarrollo de gran parte de sus tejidos dentro del sustrato que habitan, no fue posible determinar con exactitud el número de individuos, ni estimar su cobertura (Hofman y Kielman, 1992). Por esto, se decidió modificar la metodología y solo registrar su frecuencia de aparición (\%) mediante la siguiente ecuación:

$$
F A \%=\frac{N C E}{T C} 100
$$

Donde,

FA \%: Porcentaje de frecuencia de aparición

NCE: Número de marcos de $1 \mathrm{~m}^{2}$ con presencia de la esponja perforadora

TC: Total de marcos de $1 \mathrm{~m}^{2}$ por sitio de muestreo

La determinación del grado de similitud entre sitios consideró las abundancias relativas de todas las especies de esponjas en cada sitio. Se usó el índice de similitud BrayCurtis como medida de la afinidad entre sitios y el ligamiento promedio como método de fusión de los pares de muestras; así como la prueba de Simprof con un nivel de significación del $5 \%$ para determinar si el agrupamiento entre sitios era significativo. Para comparar la similitud de las variables de profundidad, porcentaje de sustrato disponible y tasa de sedimentación versus las abundancias relativas de esponjas entre sitios, se realizó un análisis de coordenadas principales (PCO) (Anderson et al., 2008). Este método revela los tamaños relativos y las direcciones de efectos en diseños experimentales complejos sin trazar las muestras. El análisis se realizó con los programas Primer v7 vs Permanova add-on (Primer-E Ltd, Plymouth, UK).

\section{RESULTADOS}

\section{Especies registradas}

En un total de 200 unidades de muestreo, se cuantificaron 3048 individuos y se identificaron 43 especies correspondientes a dos clases, a 11 órdenes, a 22 familias y a 28 géneros, según la clasificación propuesta por Morrow y Cárdenas (2015) (Anexo 1). De las 43 especies, 28 ya habían sido reportadas para el Caribe costarricense, 13 fueron nuevos registros (Tabla 2), dos fueron identificadas solo hasta género, y ocho especies no pudieron ser identificadas taxonómicamente.

\section{Cobertura y abundancias relativas}

La cobertura total del sustrato por parte de las esponjas no sobrepasó el 6,1 \% en ninguno de los sitios, siendo Perezoso y Pequeño (3,0 \%) aquellos con mayor y inhabit, it was not possible to determine exactly the number of individuals, nor estimate their coverage (Hofman and Kielman, 1992). Therefore, it was decided to modify the methodology and only record its occurrence frequency (\%) using the following equation:

$$
F A \%=\frac{N C E}{T C} 100
$$

Where,

FA \%: Occurrence frequency percentage

NCE: Number of $1 \mathrm{~m}^{2}$ frames with the presence of the perforating sponge

TC: Total frames of $1 \mathrm{~m}^{2}$ per sampling site

The determination of the degree of similarity between sites considered the relative abundances of all sponge species at each site. The Bray-Curtis similarity index was used as a measure of the affinity between sites and the average linkage as the fusion method of the samples pairs; as well as the Simprof test with a significance level of $5 \%$ to determine if the grouping between sites was significant. To compare the similarity of the depth variables, percentage of the available substrate, and sedimentation rate versus the relative abundances of sponges between sites, a principal coordinate analysis (PCO) was performed (Anderson et al., 2008). This method reveals the relative sizes and directions of effects in complex experimental designs without plotting the samples. The analysis was performed with the PRIMER v7 vs PERMANOVA add-on programs (PRIMER-E Ltd, Plymouth, UK).

\section{RESULTS}

\section{Registered species}

In a total of 200 sampling units, 3048 individuals were quantified and 43 species corresponding to two classes, 11 orders, 22 families, and 28 genera were identified, according to the classification proposed by Morrow and Cárdenas (2015) (Annex 1). Of the 43 species, 28 had already been reported for the Costa Rican Caribbean, 13 were new records (Table 2), two were identified only up to genus, and eight species could not be taxonomically identified.

\section{Coverage and relative abundances}

The total coverage of the substrate by the sponges did not exceed $6.1 \%$ in any of the sites, with Perezoso and Pequeño (3.0 \%) being the sites with the highest and lowest coverage, respectively (Table 2). The species with the 
menor cobertura, respectivamente (Tabla 2). Las especies con mayor abundancia relativa en Perezoso fueron Niphates erecta (59,3\%), Iotrochota birotulata (14,0 \%) y Scopalina ruetzleri $(5,2 \%)$. I. birotulata $(1,1 \%)$ y $N$. erecta $(1,8 \%)$ también presentaron las mayores coberturas relativas en este sitio junto con C. caribbaea (2,0 \%) (Tabla 2).

En el caso de Pequeño, Ircinia felix (15,9\%), la Especie 4 (13,3\%) y S. ruetzleri (12,3\%), tuvieron mayores abundancias relativas. Sin embargo, de estas esponjas, sólo I. felix $(1,0 \%)$ y la Especie 4 (0,8 \%) mostraron las mayores coberturas relativas, seguidas de Haliclona caerulea $(0,2 \%)$ (Tabla 2).

En Coral Garden, N. erecta $(28,4 \%)$, I. birotulata (13,7 \%) y S. ruetzleri (12,2\%) presentaron las mayores abundancias relativas, similar que en Perezoso. La especie Svenzea zeai solo fue registrada en este sitio, donde presentó la mayor cobertura relativa $(1,3 \%)$ junto con otras esponjas como I. birotulata $(0,9 \%)$ y $N$. erecta $(0,6 \%)$ (Tabla 2$)$.

En el 0,36, las mayores abundancias relativas estuvieron representadas por $N$. erecta (26,9\%), Mycale laevis $(15,2 \%)$ y Clathria curacaoensis $(7,8 \%)$. La esponja I. felix tuvo la mayor cobertura relativa $(0,9 \%)$, seguida de N. erecta $(0,8 \%)$ e Ircinia campana $(0,7 \%)$. En este sitio también se observó el mayor número de individuos (982) entre los cuatro sitios muestreados y, por ende, presentó la mayor densidad de esponjas (19,6 individuos $\left./ \mathrm{m}^{2}\right)$ (Tabla 2). highest relative abundance in Perezoso were Niphates erecta (59.3\%), Iotrochota birotulata (14.0\%), and Scopalina ruetzleri (5.2\%). I. birotulata (1.1\%) and N. erecta (1.8\%) also presented the highest relative coverage at this site along with C. caribbaea (2.0\%) (Table 2).

In the case of Pequeño, Ircinia felix (15.9\%), Species 4 (13.3\%) and S. ruetzleri (12.3\%), had higher relative abundances. However, of these sponges, only I. felix $(1.0 \%)$ and Specie $4(0.8 \%)$ showed the highest relative coverage, followed by Haliclona caerulea $(0.2 \%)$ (Table 2).

In Coral Garden, N. erecta (28.4 \%), I. birotulata $(13.7 \%)$ and S. ruetzleri (12.2\%) presented the highest relative abundances, similar to that of Perezoso. The Svenzea zeai species was only registered at this site, where it presented the highest relative coverage (1.3\%) along with other sponges such as I. birotulata $(0.9 \%)$ and $N$. erecta $(0.6 \%)$ (Table 2$)$.

In 0.36 , the highest relative abundances were represented by N. erecta (26.9\%), Mycale laevis (15.2\%), and Clathria curacaoensis (7.8 \%). The I. felix sponge had the highest relative coverage $(0.9 \%)$, followed by $N$. erecta $(0.8 \%)$ and Ircinia campana $(0.7 \%)$. The highest number of individuals was also observed at this site and (982) among the four sampled sites and, therefore, had the highest density of sponges (19.6 individuals $/ \mathrm{m}^{2}$ ) (Table 2).

Tabla 2. Abundancia, cobertura y densidad de especies de esponjas por sitio de muestreo.

Table 2. Abundance, coverage, and density of sponge species by sampling site.

\begin{tabular}{|c|c|c|c|c|c|c|c|c|}
\hline \multirow{2}{*}{$\begin{array}{c}\text { Sitio/Site } \\
\text { Especie/Species }\end{array}$} & \multicolumn{2}{|c|}{ Perezoso } & \multicolumn{2}{|c|}{ Pequeño } & \multicolumn{2}{|c|}{ Coral Garden } & \multicolumn{2}{|c|}{ El 0.36} \\
\hline & AR \% & $\mathrm{CR} \%$ & AR \% & $\mathrm{CR} \%$ & AR $\%$ & $\mathrm{CR} \%$ & AR $\%$ & $\mathrm{CR} \%$ \\
\hline Agelas schmidti* & - & - & - & - & - & - & 0.1 & $>0.1$ \\
\hline Aiolochroia crassa & - & - & - & - & 0.6 & $>0.1$ & 0.1 & $>0.1$ \\
\hline Aplysina cauliformis & - & - & 7.2 & 0.1 & 2.3 & 0.1 & 0.4 & $>0.1$ \\
\hline Aplysina insularis & - & - & 3.4 & 0.1 & 0.4 & $>0.1$ & 1.0 & $>0.1$ \\
\hline Aplysina lacunosa & - & - & - & - & 0.7 & 0.1 & - & - \\
\hline Aplysina sp. & - & - & - & - & 0.3 & $>0.1$ & - & - \\
\hline Callyspongia pallida & - & - & - & - & - & - & 0.7 & $>0.1$ \\
\hline Callyspongia vaginalis & - & - & - & - & 0.3 & $>0.1$ & 4.3 & 0.7 \\
\hline Cinachyrella alloclada & 1.0 & 0.1 & 2.8 & 0.2 & 2.3 & 0.2 & - & - \\
\hline Cinachyrella apion* & 3.6 & 0.2 & 3.2 & 0.1 & 1.8 & 0.1 & 0.2 & $>0.1$ \\
\hline Cinachyrella kuekenthali* & - & - & 0.6 & 0.1 & - & - & - & - \\
\hline Clathria curacaoensis & - & - & 1.1 & $>0.1$ & 0.3 & 0.1 & 7.8 & 0.4 \\
\hline Clathria echinata* & - & - & - & - & 0.8 & $>0.1$ & - & - \\
\hline Clathria venosa* & 2.7 & 0.2 & - & - & - & - & - & - \\
\hline
\end{tabular}




\begin{tabular}{|c|c|c|c|c|c|c|c|c|}
\hline \multirow{2}{*}{$\frac{\text { Sitio/Site }}{\text { Especie/Species }}$} & \multicolumn{2}{|c|}{ Perezoso } & \multicolumn{2}{|c|}{ Pequeño } & \multicolumn{2}{|c|}{ Coral Garden } & \multicolumn{2}{|c|}{ El 0.36} \\
\hline & AR $\%$ & $\mathrm{CR} \%$ & AR $\%$ & $\mathrm{CR} \%$ & AR $\%$ & CR \% & AR $\%$ & $\mathrm{CR} \%$ \\
\hline Cliona caribbaea & 1.1 & 2.0 & - & - & 1.6 & 0.1 & - & - \\
\hline Dragmacidon lunaecharta* & - & - & 0.6 & $>0.1$ & 1.3 & $>0.1$ & 2.0 & 0.1 \\
\hline Dragmacidon reticulatum & - & - & 3.4 & $>0.1$ & 1.0 & $>0.1$ & 4.7 & 0.1 \\
\hline Ectyoplasia ferox & - & - & 0.2 & $>0.1$ & 5.8 & 0.4 & 0.8 & 0.2 \\
\hline Especie/Specie 1 & 0.1 & $>0.1$ & - & - & - & - & - & - \\
\hline Especie/Specie 2 & 0.3 & $>0.1$ & - & - & 0.1 & $>0.1$ & - & - \\
\hline Especie/Specie 3 & 0.6 & $>0.1$ & - & - & 0.6 & $>0.1$ & 0.2 & $>0.1$ \\
\hline Especie/Specie 4 & 0.8 & $>0.1$ & 13.3 & 0.8 & - & - & 0.1 & $>0.1$ \\
\hline Especie/Specie 5 & - & - & 1.5 & $>0.1$ & - & - & - & - \\
\hline Especie/Specie 6 & - & - & 0.2 & $>0.1$ & - & - & - & - \\
\hline Especie/Specie 7 & 0.3 & $>0.1$ & 1.1 & $>0.1$ & 0.1 & $>0.1$ & - & - \\
\hline Especie/Specie 8 & - & - & - & - & 0.3 & $>0.1$ & - & - \\
\hline Haliclona caerulea* & 0.8 & $>0.1$ & 11.8 & 0.2 & - & - & 1.2 & 0.2 \\
\hline Halisarca caerulea & - & - & - & - & 0.1 & $>0.1$ & 0.1 & $>0.1$ \\
\hline Iotrochota birotulata & 14.0 & 1.1 & 5.1 & 0.1 & 13.6 & 0.9 & 2.4 & 0.1 \\
\hline Ircinia campana & - & - & - & - & - & - & 2.2 & 0.7 \\
\hline Ircinia felix & 2.3 & 0.2 & 15.9 & 1.0 & - & - & 7.2 & 0.9 \\
\hline Monanchora arbuscula & - & - & - & - & - & - & 1.6 & 0.1 \\
\hline Mycale laevis & 3.3 & 0.2 & 0.9 & $>0.1$ & 8.7 & 0.2 & 15.2 & 0.4 \\
\hline Mycale microsigmatosa* & 0.1 & $>0.1$ & - & - & - & - & - & - \\
\hline Neopetrosia proxima & 0.5 & 0.1 & 0.4 & $>0.1$ & 0.6 & 0.1 & 4.2 & 0.2 \\
\hline Niphates erecta & 59.3 & 1.8 & 9.1 & 0.1 & 28.3 & 0.6 & 26.9 & 0.8 \\
\hline Niphates sp. & 1.7 & $>0.1$ & - & - & 6.9 & 0.2 & 3.6 & 0.2 \\
\hline Petrosia pellasarca & - & - & - & - & 0.1 & 0.1 & 0.2 & $>0.1$ \\
\hline Placospongia intermedia & 0.3 & 0.1 & 0.2 & $>0.1$ & - & - & - & - \\
\hline Plakinastrella onkodes* & - & - & - & - & 0.1 & $>0.1$ & - & - \\
\hline Plakortis angulospiculatus* & 0.1 & $>0.1$ & - & - & - & - & - & - \\
\hline Plakortis sp.* & 0.3 & $>0.1$ & - & - & 0.4 & $>0.1$ & 0.3 & $>0.1$ \\
\hline Prosuberites laughlini & 0.1 & $>0.1$ & - & - & - & - & - & - \\
\hline Scopalina ruetzleri & 5.2 & 0.1 & 12.3 & 0.1 & 12.1 & 0.3 & 6.8 & 0.2 \\
\hline Spirastrella coccinea & 1.4 & $>0.1$ & 5.3 & 0.1 & 0.7 & $>0.1$ & 4.8 & 0.2 \\
\hline Svenzea zeai* & - & - & - & - & 7.2 & 1.3 & - & - \\
\hline Verongula rígida & - & - & - & - & 0.3 & 0.1 & - & - \\
\hline Xestospongia muta & - & - & 0.6 & $>0.1$ & 0.4 & 0.6 & 0.5 & 0.3 \\
\hline $\begin{array}{l}\text { Total de unidades de muestreo/ } \\
\text { Total sampling units }\end{array}$ & & & & & & & & \\
\hline $\begin{array}{l}\text { Total de individuos/ } \\
\text { Total individuals }\end{array}$ & & & & & & & & \\
\hline $\begin{array}{l}\text { Cobertura total de esponjas/ } \\
\text { Total sponge coverage }(\%)\end{array}$ & & & & & & & & \\
\hline $\begin{array}{l}\text { Densidad total de esponjas (individuos } / \mathrm{m}^{2} \text { )/ } \\
\text { Total density of sponges (individuals } / \mathrm{m}^{2} \text { ) }\end{array}$ & & & & & & & & \\
\hline
\end{tabular}


El porcentaje de frecuencia de aparición de esponjas perforadoras del género Siphonodictyon se mantuvo por debajo del $45 \%$ en todos los sitios. En Coral Garden $S$. brevitubulatum fue la especie perforadora más frecuente (38\%); además, este fue el único sitio donde se registró $S$. coralliphagum (2\%). La especie S. xamaycaense resultó ser un nuevo registro para el país y se presentó solamente en Perezoso, donde tuvo un mayor porcentaje de frecuencia de aparición (24\%) que S. brevitubulatum (16\%). En el parche arrecifal Pequeño, no se registraron especies de este género durante el muestreo (Figura 2).
The occurrence frequency percentage of boring sponges of the genus Siphonodictyon remained below $45 \%$ at all sites. In Coral Garden S. brevitubulatum was the most frequent boring species (38\%); furthermore, this was the only site where $S$. coralliphagum was registered (2\%). The $S$. xamaycaense species turned out to be a new registry for the country and it was only presented in Perezoso, where it had a higher occurrence frequency percentage (24\%) than S. brevitubulatum (16\%). In Pequeño reef patch, no species of this genus were recorded during the sampling (Figure 2).

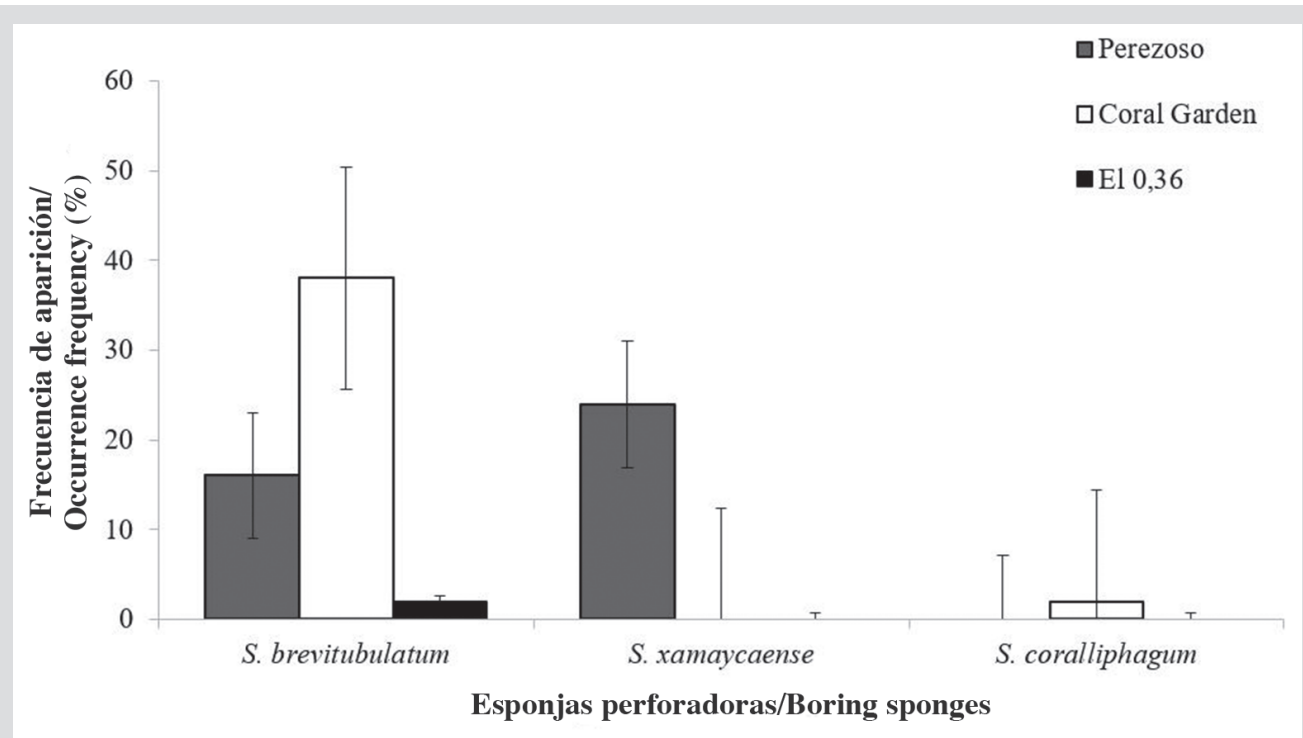

Figura 2. Frecuencia de aparición porcentual de esponjas perforadoras del género Siphonodictyon en los sitios de muestreo.
Figure 2. Occurrence frequency percentage of boring sponges of the genus Siphonodictyon at the sampling sites.

\section{Índices de diversidad}

En Coral Garden se registró el mayor número de especies de esponjas con un total de 34. A pesar de esto, mostró valores de heterogeneidad, equitatividad y dominancia de especies muy similares a los de Pequeño y el 0,36 . Por lo tanto, al aplicar el diagrama de grado de severidad y pronosticabilidad ambiental, se obtuvo que las esponjas de estos tres parches arrecifales viven bajo condiciones de algo severas a favorables y de casi constantes a constantes. Esto contrasta con lo encontrado para Perezoso, el cual, debido a sus valores menores de heterogeneidad y equitatividad, se clasificó como un ambiente severo e impredecible. Sumado a lo anterior, Perezoso presentó el único valor de dominancia mayor a 0,1 (Tabla 3 ).
Diversity indices

Coral Garden registered the largest number of sponge species with a total of 34. Despite this, it showed values of heterogeneity, evenness, and dominance of species very similar to those of Pequeño and 0.36. Therefore, when applying the diagram of the severity degree and environmental predictability, it was found that the sponges of these three reef patches live under somewhat severe to favorable conditions and from almost constant to constant. This contrasts with what was found for Perezoso, which, due to its lower values of heterogeneity and evenness, was classified as a severe and unpredictable environment. In addition to the above, Perezoso presented the only dominance value higher than 0.1 (Table 3). 
Tabla 3. Índices de diversidad y grado de severidad y pronosticabilidad ambiental de los sitios de muestreo.
Table 3. Diversity indices and degree of severity and environmental predictability of the sampling sites.

\begin{tabular}{|c|c|c|c|c|}
\hline \multirow{2}{*}{ Índice/Index } & \multicolumn{4}{|c|}{ Sitio/Site } \\
\hline & Perezoso & Pequeño & Coral Garden & El 0.36 \\
\hline $\mathrm{S}$ & 25 & 23 & 34 & 29 \\
\hline $\mathrm{H}^{\prime}$ & 1.6 & 2.6 & 2.4 & 2.5 \\
\hline $\mathrm{J}$ ' & 0.5 & 0.8 & 0.7 & 0.8 \\
\hline D & 0.4 & 0.1 & 0.1 & 0.1 \\
\hline $\begin{array}{l}\text { Grado de severidad y } \\
\text { pronosticabilidad ambiental/ } \\
\text { Degree of severity and } \\
\text { environmental predictability }\end{array}$ & $\begin{array}{l}\text { Severo e impredecible/ } \\
\text { Severe and unpredictable }\end{array}$ & $\begin{array}{l}\text { Favorable y constante/ } \\
\text { Favorable and constant }\end{array}$ & $\begin{array}{l}\text { Algo severo y casi } \\
\text { constante/Slightly severe } \\
\text { and almost constant }\end{array}$ & $\begin{array}{c}\text { Favorable y casi } \\
\text { constante/Favorable } \\
\text { and almost constant }\end{array}$ \\
\hline
\end{tabular}

S: número de especies, H': heterogeneidad de Shannon, J': equitatividad de Pielou y D: dominancia de Simpson.

\section{Factores abióticos y similitud entre sitios}

Las tasas de sedimentación se vieron acentuadas durante la transición de la época seca a la lluviosa (octubrediciembre) y disminuidas con el paso de la época lluviosa a la seca (agosto-septiembre y septiembre-octubre); excepto en el 0,36 donde las tasas se mantuvieron relativamente constantes y no superaron $\operatorname{los} 32,4 \pm 6,0 \mathrm{mg} / \mathrm{cm}^{2} /$ día (Figura $3)$. Las mayores tasas y variaciones de sedimentación por períodos se dieron en Perezoso y en Pequeño. Sin embargo, no parece que lo anterior tenga un efecto en la similitud entre los sitios con respecto a la abundancia relativa de las especies de esponjas presentes (Figura 4).

La disponibilidad de sustrato fue igual o mayor a $67,0 \%$ en todos los sitios. Este valor mínimo correspondió a Coral Garden, donde solo se encontró pavimento calcáreo desnudo. La mayor cantidad de sustrato disponible lo presentaron Perezoso (74,0 \%) y Pequeño (69,1 \%). En ambos sitios se registraron tres de los cuatro tipos de sustrato encontrados en este estudio. No obstante, en Perezoso predominó el pavimento calcáreo desnudo (48,7 \%) y en Pequeño, el pavimento calcáreo con sedimentos $(35,1 \%)$. Por su lado, en el 0,36 predominó el pavimento calcáreo con arena gruesa (66,2\%) y fue el único sitio donde se encontró este tipo de sustrato (Tabla 4, Figura 5).

El ámbito de profundad varió entre 5,0 $\pm 0,9 \mathrm{y}$ $18 \pm 3,4 \mathrm{~m}$, siendo Pequeño el sitio más somero y Coral Garden, el más profundo (Figura 6). Los sitios más parecidos entre sí en base a la abundancia relativa de esponjas fueron Perezoso y Coral Garden (1 y 3), con una importante diferenciación con respecto a Pequeño y el 0,36 (Figura 4, Figura 5 y Figura 6).
S: number of species, H': heterogeneity of Shannon, J': evenness of Pielou and D: dominance of Simpson.

\section{Abiotic factors and similarity between sites}

Sedimentation rates were accentuated during the transition from the dry to the rainy season (OctoberDecember) and decreased with the passage from the rainy to the dry season (August-September, and SeptemberOctober); except in 0.36 where the rates remained relatively constant and did not exceed $32.4 \pm 6.0 \mathrm{mg} / \mathrm{cm}^{2} /$ day (Figure 3 ). The highest sedimentation rates and variations by periods were obtained in Perezoso and Pequeño. However, it does not appear that the above affect the similarity between the sites with respect to the relative abundance of the sponge species present (Figure 4).

Substrate availability was equal to or greater than $67.0 \%$ at all sites. This minimum value corresponded to Coral Garden, where the only bare calcareous pavement was found. The largest amount of available substrate was presented by Perezoso (74.0\%) and Pequeño (69.1\%). In both sites, three of the four types of substrate found in this study were recorded. However, in Perezoso, the bare calcareous pavement predominated $(48.7 \%)$ while the calcareous pavement with sediments $(35.1 \%)$ predominated in Pequeño. On the other hand, in 0.36 the calcareous pavement with coarse sand $(66.2 \%)$ predominated and it was the only place where this type of substrate was found (Table 4, Figure 5).

The depth range varied between $5.0 \pm 0.9$ and $18 \pm 3.4 \mathrm{~m}$, with Pequeño being the shallowest site and Coral Garden the deepest (Figure 6). The most similar sites to each other based on the relative abundance of sponges were Perezoso and Coral Garden (1 and 3), with an important differentiation to Pequeño and 0.36 (Figure 4, Figure 5, and Figure 6). 


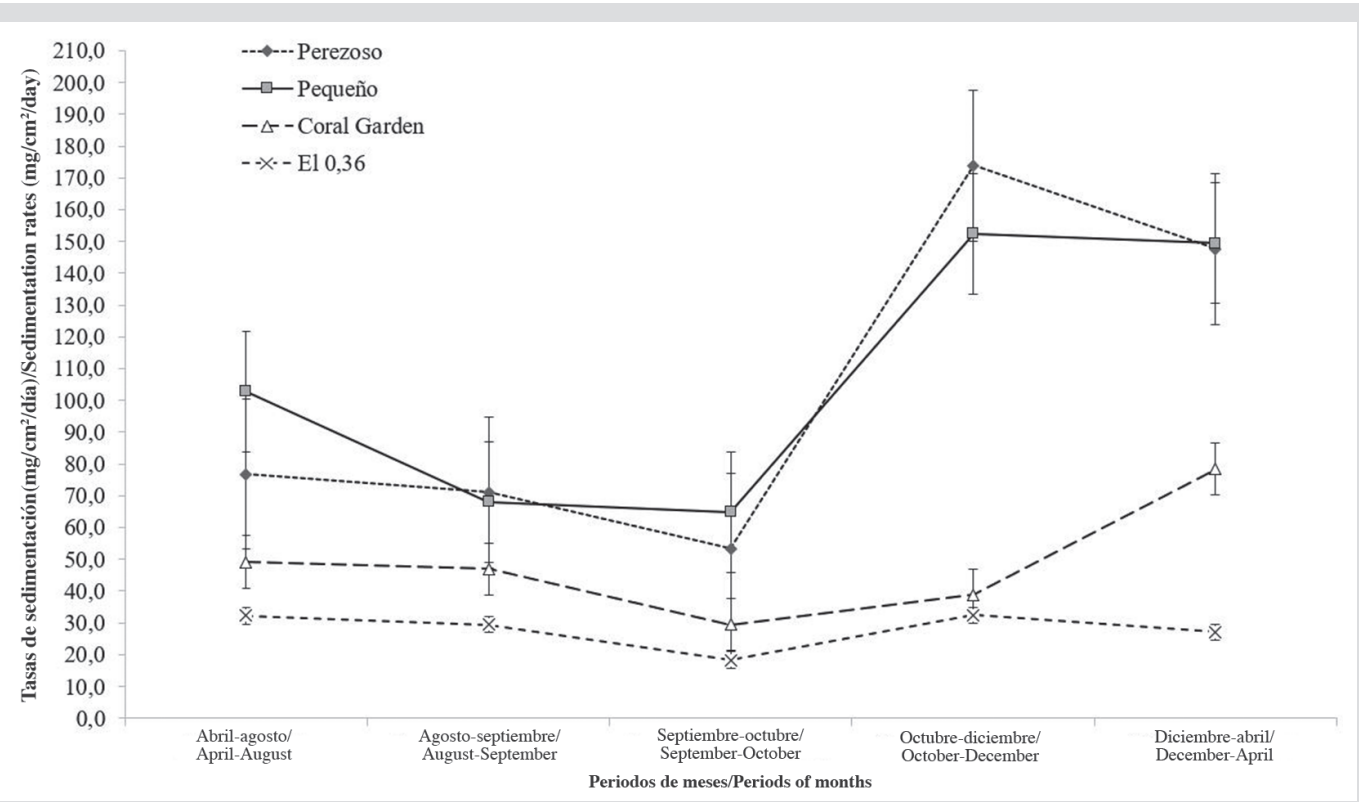

Figura 3. Tasas promedio de sedimentación por períodos y por sitios de muestreo.

Figure 3. Average sedimentation rates by period and by sampling sites.

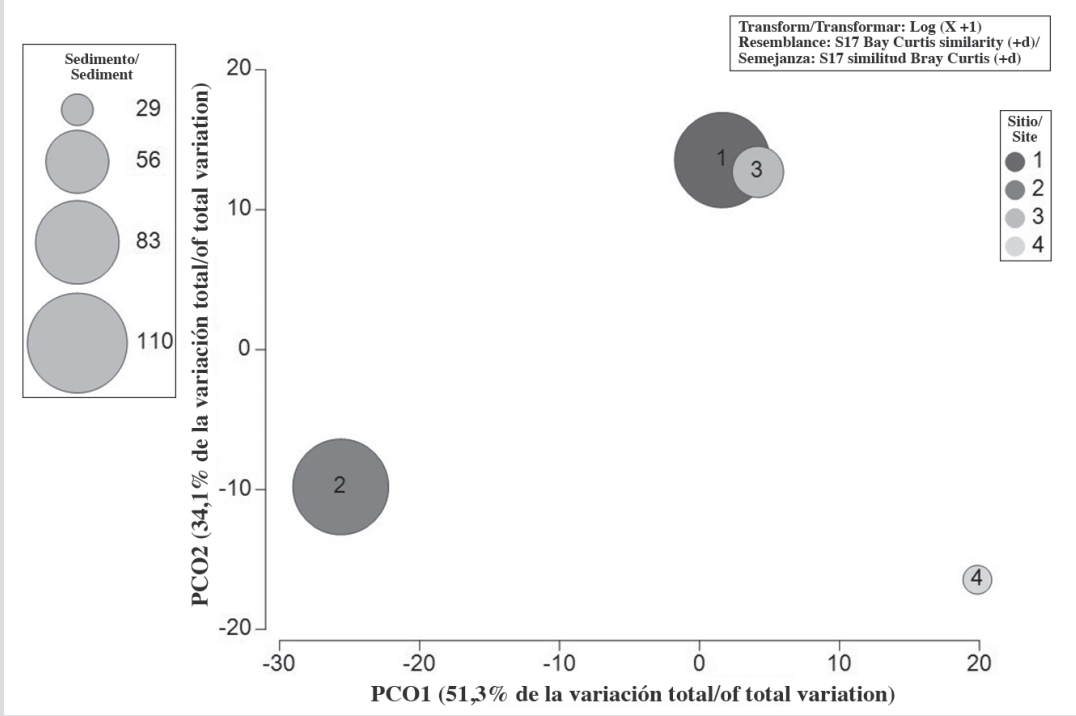

Figura 4. Similitud entre los sitios de muestro respecto a la abundancia relativa de esponjas y a las tasas promedio de sedimentación $\left(\mathrm{mg} / \mathrm{cm}^{2} /\right.$ día). 1) Perezoso, 2) Pequeño, 3) Coral Garden, 4) el 0,36.
Figure 4. Similarity between the sampling sites with respect to the relative abundance of sponges and the average sedimentation rates (mg/ $\mathrm{cm}^{2} /$ day). 1) Perezoso, 2) Pequeño, 3) Coral Garden, 4) 0.36.
Tabla 4. Tipo de sustrato disponible (\%) por sitio.

\section{Tipo de sustrato/Substrate type}

Pavimento calcáreo (PC)/Limestone floor (LF)

$\mathrm{PC}$ con sedimentos/LF with sediment

$\mathrm{PC}$ con arena gruesa/LF with coarse sand

Fondo con sedimentos/Background with sediment

Total

Table 4. Type of available substrate (\%) by the site.

\begin{tabular}{|c|c|c|c|}
\hline \multicolumn{5}{|c|}{ Sitio/Site } \\
\hline Perezoso & Pequeño & Coral Garden & El 0.36 \\
\hline 48.7 & 27.8 & 67.0 & 1.2 \\
1.8 & 35.1 & - & - \\
\hline- & - & - & 66.2 \\
\hline 23.5 & 6.2 & - & - \\
\hline 74.0 & 69.1 & 67.0 & 67.4 \\
\hline
\end{tabular}




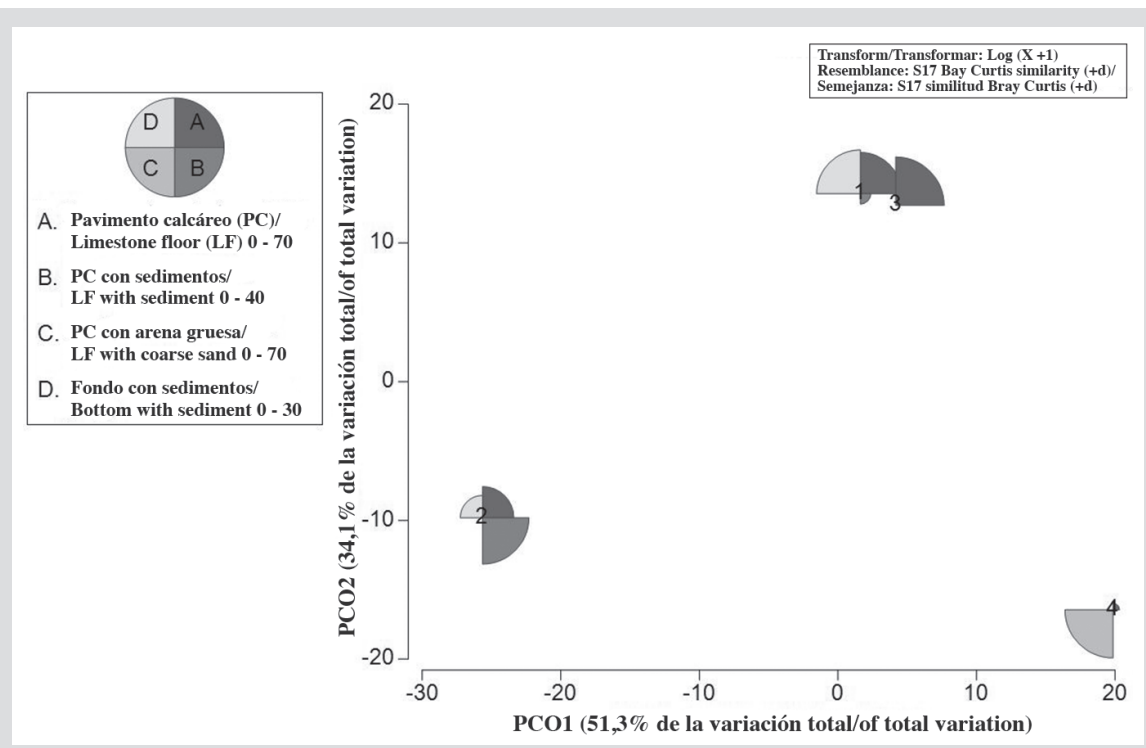

Figura 5. Similitud entre los sitios de muestro respecto a la abundancia relativa de esponjas y al porcentaje de sustrato disponible 1) Perezoso, 2) Pequeño, 3) Coral Garden, 4) El 0,36.

Figure 5. Similarity between sampling sites to the relative abundance of sponges and the percentage of available substrate 1) Perezoso, 2) Pequeño, 3) Coral Garden, 4) 0.36.

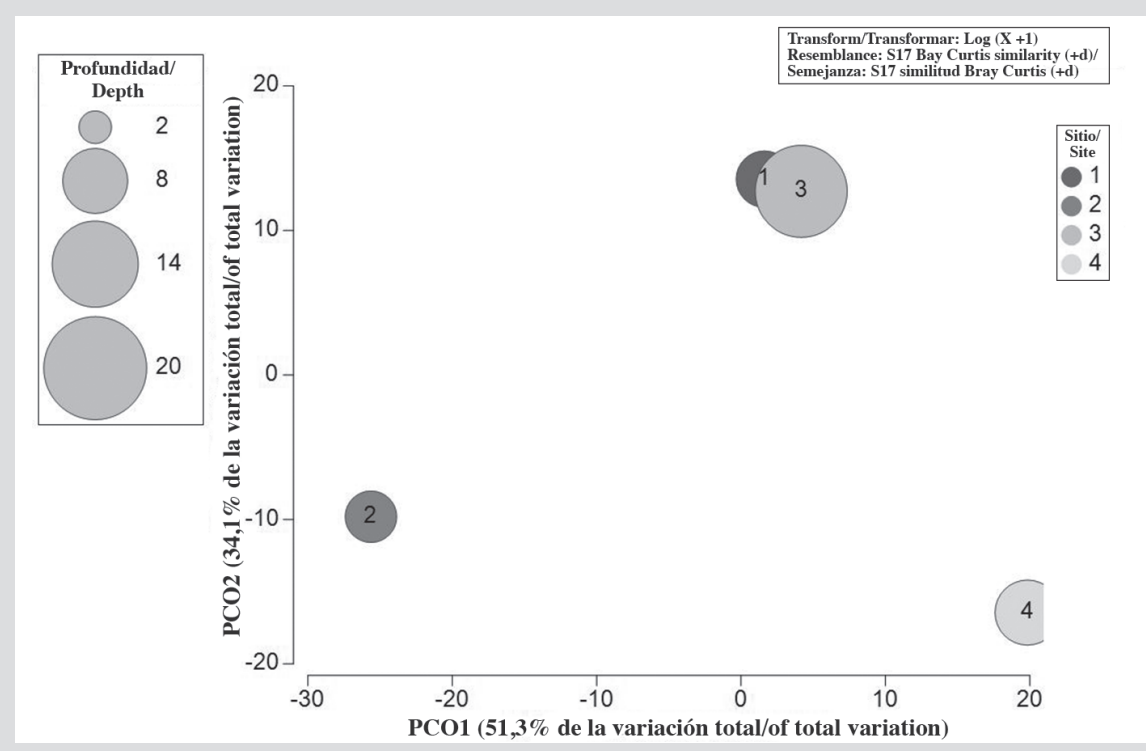

Figura 6. Similitud entre los sitios de muestro respecto a la abundancia relativa de esponjas y a la profundidad promedio (m). 1) Perezoso, 2) Pequeño, 3) Coral Garden, 4) el 0,36.
Figure 6. Similarity between the sampling sites to the relative abundance of sponges and the average depth (m). 1) Perezoso, 2) Pequeño, 3) Coral Garden, 4) 0.36 .

\section{DISCUSIÓN}

\section{Especies registradas}

El registro de 13 especies de esponjas no reportadas anteriormente para el Caribe costarricense demuestra la insuficiente investigación desarrollada en el país sobre este grupo. Esto fue señalado por Cortés et al. (2009), quienes con una campaña de recolecta de especímenes en esta región del país incrementaron el número de nuevos registros

\section{DISCUSSION}

\section{Registered species}

The record of 13 sponge species not previously reported for the Costa Rican Caribbean demonstrates the insufficient research carried out in the country on this group. This was pointed out by Cortés et al. (2009), who with a specimen collection campaign in this region of the country increased the number of new records in 28 species. The 
en 28 especies. Es probable que el desarrollo de estudios relacionados con este grupo en otros parches arrecifales y ecosistemas (manglares, pastos marinos, entre otros) del área lleven a nuevos registros, así como al descubrimiento de nuevas especies, lo cual podría ayudar a entender mejor los patrones de distribución de las esponjas marinas y las dinámicas y los procesos que ocurren en los ecosistemas donde se encuentran.

\section{Cobertura y abundancia relativas}

En cuanto a la cobertura de esponjas, ninguno de los cuatro sitios estudiados mostró ser particularmente favorable para el crecimiento horizontal de los poríferos. Esto es evidente si realizamos una comparación con otros arrecifes del Caribe como los de Santa Marta (Zea, 1994) y el golfo de Urabá (Valderrama y Zea, 2003) en Colombia, donde las esponjas cubren por encima del $5,0 \%$ del sustrato y pueden alcanzar hasta un 33,3\% de la cobertura total. Los porcentajes de cobertura encontrados en este estudio $(\mathrm{CR}<6,1 \%)$ se ubican en un rango similar a los documentados en la costa oriental de la bahía de Cochinos, Cuba, por Caballero et al. (2009). Dichos autores consideraron porcentajes de cobertura de esponjas por debajo del $8 \%$ como bajos y posiblemente asociados a arrecifes en estado natural con predominancia de corales.

Solo dos de las especies registradas presentaron coberturas mayores a $1,5 \%, C$. caribbaea $(2,0 \%)$ y $N$. erecta $(1,8 \%)$, específicamente en Perezoso. Estas esponjas conformaron más de la mitad de la cobertura de estos organismos en el sitio. La especie $N$. erecta también resultó ser la más abundante $(26,9-59,3 \%)$ en tres de los cuatro sitios de muestreo (Perezoso, Coral Garden y el 0,36) y representó más de la mitad de los individuos en Perezoso. Esto se reflejó en el índice de dominancia obtenido $(\mathrm{D}=0,4)$ para este sitio.

Se considera que Niphates erecta es una especie heterótrofa, no posee endosimbiontes fotosinténticos, y depende estrictamente de la filtración como fuente de alimento (Romero et al., 2013). Por esto, es común encontrar altas abundancias de dicha esponja en sitios con condiciones ambientales similares a las de Perezoso, donde la turbulencia, corrientes, descargas de sedimentos y turbidez son altas. Ejemplos documentados de lo anterior incluyen los fondos rocoso-arenosos de la isla Nelson en Trinidad y Tobago (Hubbard, 1990), las zonas coralinas del golfo de Urabá en Colombia (Valderrama y Zea, 2003), playa Mero y Punta Brava en Venezuela (Romero et al., development of studies related to this group in other reef patches and ecosystems (mangroves, seagrasses, among others) in the area is likely to lead to new records, as well as the discovery of new species, which could help to better understand the distribution patterns of sea sponges, as well as the dynamics and processes that occur in the ecosystems where they are found.

\section{Relative coverage and abundance}

Regarding sponge coverage, none of the four studied sites showed to be particularly favorable for the horizontal growth of the poriferans. This is evident if we make a comparison with other reefs in the Caribbean such as those of Santa Marta (Zea, 1994) and Gulf of Urabá (Valderrama and Zea, 2003) in Colombia where sponges cover over $5.0 \%$ of the substrate and it can reach up to $33.3 \%$ of the total coverage. The coverage percentages found in this study $(\mathrm{CR}<6.1 \%)$ are in a similar range to those documented in the eastern coast of Cochinos bay, Cuba, by Caballero et al. (2009). These authors considered sponge cover percentages below $8 \%$ as low and possibly associated with reefs in the natural state with a predominance of corals.

Only two of the registered species had coverage higher than $1.5 \%, C$. caribbaea (2.0\%), and $N$. erecta $(1.8 \%)$, specifically in Perezoso. These sponges made up more than half of the coverage of these organisms at the site. The $N$. erecta species also turned out to be the most abundant (26.9-59.3\%) in three of the four sampling sites (Perezoso, Coral Garden, and 0.36) and represented more than half of the individuals in Perezoso. This was reflected in the dominance index obtained $(\mathrm{D}=0.4)$ for this site.

Niphates erecta is considered to be a heterotrophic species, does not have photosynthetic endosymbionts, and is strictly dependent on filtration as a food source (Romero et al., 2013). For this reason, it is common to find high abundances of this sponge in sites with environmental conditions similar to those of Perezoso, where turbulence, currents, sediment discharges, and turbidity are high. Documented examples of the above include the rockysandy bottoms of Nelson island in Trinidad and Tobago (Hubbard, 1990), the coral areas of the Gulf of Urabá in Colombia (Valderrama and Zea, 2003), Mero beach and Punta Brava in Venezuela (Romero et al., 2013). Also, $N$. erecta is frequent in mangroves and is among the five most abundant species in the shallow reefs of Bocas del Toro (Caribbean of Panama), where there is low urban and 
2013). Además, $N$. erecta es frecuente en los manglares y se encuentra entre las cinco especies más abundantes en los arrecifes someros de Bocas del Toro (Caribe de Panamá), donde existe un bajo desarrollo urbanístico y turístico, pero el tratamiento de sus aguas residuales es casi nulo (Díaz, 2005; Gotchfield et al., 2007).

\section{Diversidad y factores abióticos}

La riqueza de especies de esponjas pareció aumentar con la profundidad promedio de los sitios muestreados. Este patrón ha sido documentado en otros arrecifes de la región caribeña por Valderrama y Zea (2003) en el golfo de Urabá en Colombia y por De la Nuez et al. (2011) en el bajo de Sancho Pardo en Cuba. Sin embargo, los demás índices de diversidad calculados para este estudio no parecieron estar vinculados a ninguno de los factores abióticos considerados. Solo Perezoso mostró excepciones a esta tendencia con valores contrastantes en sus índices $\left(H^{\prime}=1,6 ; J^{\prime}=0,5 ; D=0,4\right)$, además de haber sido el único sitio clasificado como severo e impredecible al aplicar el diagrama de severidad y pronosticabilidad.

Los índices de diversidad y la clasificación dada por el diagrama para Perezoso posiblemente se vieron influenciados por la alta tasa de sedimentación anual promedio $\left(104,5 \pm 52,9 \mathrm{mg} / \mathrm{cm}^{2} /\right.$ día) que se da en el sitio. Perezoso retiene sedimentos principalmente de origen terrígeno, arrastrados desde ríos como La Estrella, Suárez y la quebrada Perezoso. Dicha sedimentación, rica en contenido orgánico, ya ha sido documentada con tasas entre los 30 y $360 \mathrm{mg} / \mathrm{cm}^{2} /$ día (Cortés y Risk, 1984); y se considera que genera efectos muy negativos en los arrecifes de Cahuita (Cortés y Jiménez, 2003). Se cree que la principal fuente estos sedimentos son las plantaciones de banano y la deforestación en el Valle de la Estrella (Cortés, 1981, 1994; Cortés y Jiménez, 2003). Este arrastre de material, generado por la erosión del suelo y la infiltración de agroquímicos en los bordes del río la Estrella, se ve favorecido por la corriente costera que viaja de noroeste a sureste en el Caribe de Costa Rica (Cortés y Jiménez, 2013), así como por la forma de mazo del PNC, la cual propicia la retención de dichos sedimentos en la parte norte donde se ubica la barrera de Perezoso.

Se ha demostrado que la biomasa de esponjas en sitios cercanos a descargas de aguas residuales y agroquímicos tiende a incrementarse en términos de abundancia, cobertura o densidad. A su vez, cuando la concentración de dichos contaminantes orgánicos aumenta, es común una disminución en la diversidad de las esponjas presentes y una proliferación de las especialistas, las tourist development, but the treatment of its wastewater is almost null (Díaz, 2005; Gotchfield et al., 2007).

\section{Diversity and abiotic factors}

Sponge species richness seemed to increase with the average depth of the sampled sites. This pattern has been documented in other reefs in the Caribbean region by Valderrama and Zea (2003) in the Gulf of Urabá in Colombia and by De la Nuez et al. (2011) in those of Bajo de Sancho Pardo in Cuba. However, the other diversity indices calculated for this study did not appear to be linked to any of the abiotic factors considered. Only Perezoso showed exceptions to this trend with contrasting values in their indices $\left(\mathrm{H}^{\prime}=1.6 ; \mathrm{J}^{\prime}=0.5 ; \mathrm{D}=0.4\right)$, in addition to being the only site classified as severe and unpredictable when applying the severity and predictability diagram.

The diversity indices and the classification given by the diagram for Perezoso were possibly influenced by the high average annual sedimentation rate $\left(104.5 \pm 52.9 \mathrm{mg} / \mathrm{cm}^{2} /\right.$ day $)$ that occurs at the site. Perezoso retain sediments mainly of terrigenous origin, carried from rivers such as La Estrella, Suárez, and the Perezoso gorge. This sedimentation, rich in organic content, has already been documented with rates between 30 and $360 \mathrm{mg} / \mathrm{cm}^{2} /$ day (Cortés and Risk, 1984); and it is considered that it generates very negative effects on the Cahuita reefs (Cortés and Jiménez, 2003). The main source of these sediments is believed to be banana plantations and deforestation in the Valle de la Estrella (Cortés, 1981, 1994; Cortés and Jiménez, 2003). This drag of material, generated by soil erosion and the infiltration of agrochemicals on the banks of the la Estrella river, is favored by the coastal current that travels from northwest to southeast in the Caribbean of Costa Rica (Cortés and Jiménez, 2013), as well as the PNC deck shape, which favors the retention of sediments in the northern part where the Perezoso barrier is located.

Sponge biomass at sites near sewage and agrochemical discharges has been shown to tend to increase in terms of abundance, coverage, or density. In turn, when the concentration of these organic pollutants increases, a decrease in the diversity of the sponges present and proliferation of specialists are common, which can be used to monitor these conditions in the environment (Rützler, 2004). This could be the case of C. venosa ( $\mathrm{AR}=2.7 \% ; \mathrm{CR}=0.2 \%)$ since this species was only found in Perezoso with coverage and relative abundance similar to that of other common species such as I. felix and 
cuales pueden ser utilizadas para el monitoreo de dichas condiciones en el ambiente (Rützler, 2004). Este podría ser el caso de $C$. venosa $(\mathrm{AR}=2,7 \% ; \mathrm{CR}=0,2 \%)$, pues esta especie fue solo encontrada en Perezoso con una cobertura y abundancia relativa similar a la de otras especies comunes como I. felix y M. laevis. Clathria venosa ha sido utilizada como especie bioindicadora de contaminación orgánica en Cuba (Busutil y Alcolado, 2012), por lo tanto, su presencia en Perezoso podría estar relacionada con los contaminantes que son arrastrados en el sedimento por ríos cercanos a plantaciones bananeras como el río La Estrella.

El diagrama de severidad y pronosticabilidad debe ser usado e interpretado con cautela. Para Perezoso, dicho diagrama sí parece ser sensible a los disturbios ambientales por medio de los valores de heterogeneidad y equitatividad obtenidos en el sitio. Sin embargo, para Pequeño mostró discrepancias que no coinciden con los resultados obtenidos. Pequeño presentó una tasa de sedimentación anual promedio similar e incluso mayor que Perezoso $\left(107,6 \pm 42,3 \mathrm{mg} / \mathrm{cm}^{2} /\right.$ día $)$ y, aun así, se clasificó como un ambiente favorable y constante debido a los valores obtenidos en heterogeneidad $(2,6)$ y equitatividad $(0,8)$.

La incidencia de una alta sedimentación en Puerto Viejo ha sido ya documentada por Cortés y Jiménez (2003). No obstante, la composición y la dinámica de los sedimentos en el sitio parece ser distinta a la de Perezoso. Mientras que en Perezoso los sedimentos procesados eran muy finos, de color negro, parecían ser en su mayoría de origen terrígeno y contenían gran cantidad de materia orgánica en descomposición, en Pequeño los sedimentos poseían una coloración más clara, partículas más gruesas combinadas con arena y menor cantidad de materia orgánica en descomposición. Además, los sedimentos en Perezoso se acumulaban y colmataban muy fácilmente en las paredes y en el fondo de la barrera, contrario a Pequeño, donde se depositaban en algunas grietas, pendientes y en los fondos con sedimentos arenosos.

Lo anterior podría indicar que la composición de los sedimentos, la topografía del fondo y la dinámica de las corrientes permitieron el desplazamiento y la deposición de los sedimentos fuera y en los alrededores del parche, evitando que la sedimentación tuviera un efecto tan pronunciado en la diversidad de esponjas en Pequeño. Asimismo, existe la posibilidad de que las altas tasas de sedimentación en este sitio no tuvieran tanto efecto sobre la composición, diversidad y abundancia de las especies de esponjas como sí pudieron tenerlo sobre su cobertura. Dicho
M. laevis. Clathria venosa has been used as a bioindicator species of organic contamination in Cuba (Busutil and Alcolado, 2012), therefore, its presence in Perezoso could be related to the contaminants that are dragged into the sediment by rivers near banana plantations such as $\mathrm{La}$ Estrella river.

The severity and predictability diagram should be used and interpreted with caution. For Perezoso, this diagram does seem to be sensitive to environmental disturbances through the values of heterogeneity and fairness obtained at the site. However, for Pequeño, it showed discrepancies that do not coincide with the results obtained. Pequeño presented an average annual sedimentation rate similar and even higher than Perezoso $\left(107.6 \pm 42.3 \mathrm{mg} / \mathrm{cm}^{2} /\right.$ day $)$ and, even so, it was classified as a favorable and constant environment due to the values obtained in heterogeneity (2.6) and fairness (0.8).

The incidence of high sedimentation in Puerto Viejo has already been documented by Cortés and Jiménez (2003). However, the composition and dynamics of the sediments at the site appear to be different from that of Perezoso. While in Perezoso the processed sediments were very fine, black in color, they seemed to be mostly of terrigenous origin and contained a large amount of decomposing organic matter; in Pequeño, the sediments had a lighter coloration, coarser particles combined with sand and less amount of decomposing organic matter. Furthermore, the sediments in Perezoso accumulated and clogged very easily on the walls and bottom of the barrier, contrary to Pequeño where they were deposited in some cracks, slopes, and on the bottoms with sandy sediments.

This could indicate that the composition of the sediments, the topography of the bottom, and the dynamics of the currents allowed the displacement and deposition of the sediments outside and around the patch, preventing sedimentation from having such a pronounced effect on diversity of sponges in Pequeño. Likewise, there is the possibility that the high sedimentation rates at this site did not have as much effect on the composition, diversity, and abundance of the sponge species as they could have on its cover. This phenomenon could be limiting and reducing the growth rates of this group due to the obstruction of their aquifer systems (Bell et al., 2015).

Another possibility is that Pequeño was undergoing a process of repopulation and colonization since the sponges' present were mainly of small sizes (less than $10 \mathrm{~cm}$ ), possibly young and that have not completed 
fenómeno podría estar limitando y reduciendo las tasas de crecimiento de este grupo debido a la obstrucción de sus sistemas acuíferos (Bell et al., 2015).

Otra posibilidad es que Pequeño se encontrara ante un proceso de repoblamiento y colonización, pues las esponjas presentes eran principalmente de tamaños pequeños (menores de $10 \mathrm{~cm}$ ), posiblemente jóvenes y no habían completado su fase crítica de colonización. Esto podría indicar un proceso de selección ambiental aún incompleto (Zea, 1993; Alcolado, 1999), posiblemente ligado al terremoto ocurrido en 1991, el cual elevó la plataforma continental en el Caribe costarricense entre 50 y $190 \mathrm{~cm}$ (Cortés et al., 1992). El fenómeno provocó la exposición del sustrato y generó altas mortalidades de invertebrados.

\section{Factores abióticos y similitud entre sitios}

El único factor que pareció explicar mejor la similitud entre sitios con respecto a la composición de especies de esponjas y sus abundancias relativas fue el porcentaje de sustrato disponible. Tanto en Perezoso como en Coral Garden, el pavimento calcáreo desnudo fue el sustrato disponible predominante $(48<\mathrm{PC} \%<67)$ y esto podría estar favoreciendo la colonización, el crecimiento y la permanencia de las especies $N$. erecta, I. birotulata y $S$. ruetzleri. Estas tres especies fueron compartidas por ambos sitios como las más abundantes a pesar de sus profundidades promedio y sus tasas de sedimentación contrastantes. Lo anterior podría estar ligado al hábito meramente heterotrófico y generalista de dichas esponjas, pues tienen la capacidad de sobrevivir y proliferar bajo el efecto de distintos estresores como fluctuaciones en la salinidad, turbidez, sedimentación iluminación y nutrientes; siempre que cuenten con un sustrato apropiado para su fijación (Nuñez et al., 2010; Romero et al., 2013).

Por otro lado, Perezoso y Coral Garden también compartieron las mayores frecuencias de aparición de esponjas perforadoras del género Siphonodictyon (40\%) y resultaron ser los únicos sitios donde se registró la presencia de la especie bioerosionadora C. caribbaea. La presencia de esponjas del género Cliona en el PNC ya había sido documentada por Cortés y Guzmán (1985), quienes registraron coberturas de hasta $1 \mathrm{~m}^{2}$, similares a lo encontrado en el presente estudio. La esponja $C$. caribbaea fue encontrada en el archipiélago de San Andrés y del Rosario, Colombia, con una distribución que variaba desde los 5 hasta los $20 \mathrm{~m}$ de profundidad y con una ligera tendencia por ser más abundante en sitios con mayor their critical phase of colonization. This could indicate a still incomplete environmental selection process (Zea, 1993; Alcolado, 1999), possibly linked to the earthquake that occurred in 1991, which raised the continental shelf in the Costa Rican Caribbean between 50 and $190 \mathrm{~cm}$ (Cortés et al., 1992). The phenomenon caused the exposure of the substrate and generated high mortality of invertebrates.

\section{Abiotic factors and similarity between sites}

The only factor that seemed to better explain the similarity between sites with respect to the composition of sponge species and their relative abundances are the percentage of the available substrate. In both Perezoso and Coral Garden, bare limestone pavement was the predominantly available substrate $(48<$ LP $\%<67)$ and this could be favouring the colonization, growth, and permanence of $N$. erecta, I. birotulata, and S. ruetzleri. These three species were shared by both sites as the most abundant despite their average depths and contrasting sedimentation rates. This could be linked to the merely heterotrophic and generalist habit of these sponges, since they can survive and proliferate under the effect of different stressors such as fluctuations in salinity, turbidity, sedimentation, illumination, and nutrients; provided they have an appropriate substrate for their fixation (Nuñez et al., 2010; Romero et al., 2013).

On the other hand, Perezoso and Coral Garden also shared the highest occurrence frequencies of boring sponges of the genus Siphonodictyon (40 \%) and were the only sites where the presence of the bio-eroding species $C$. caribbaea was recorded. The presence of sponges of the genus Cliona in the PNC had already been documented by Cortés and Guzmán (1985), who recorded coverage of up to $1 \mathrm{~m}^{2}$, similar to what was found in the present study. The C. caribbaea sponge was found in the Archipelagos of San Andrés and Rosario, Colombia, with a distribution that varied from 5 to $20 \mathrm{~m}$ deep and with a slight tendency to be more abundant in sites with greater availability of calcareous substrates as dead coral and pavement (LópezVictoria and Zea, 2005). This coincides with the depth range and the type of substrate with the highest availability presented by Perezoso and Coral Garden.

In the Caribbean, there are reports that the coverage of boring sponges of the genus Cliona has increased considerably during the last three decades (López-Victoria and Zea, 2005). This is worrisome, since these species, together with those of the Siphonodictyion genus, tend to 
disponibilidad de sustratos calcáreos como coral muerto y pavimento (López-Victoria y Zea, 2005). Esto coincide con el ámbito de profundidad y el tipo de sustrato con mayor disponibilidad que presentaron Perezoso y Coral Garden.

En el Caribe existen registros de que la cobertura de esponjas excavadoras del género Cliona ha incrementado considerablemente durante las últimas tres décadas (LópezVictoria y Zea, 2005). Esto resulta preocupante, pues dichas especies, junto con las del género Siphonodictyion, suelen tener crecimientos muy agresivos y afectaciones considerables en los arrecifes cuando su abundancia y cobertura son altas. Por ejemplo, la excavación originada por estas esponjas puede llegar a ocasionar el quiebre de grandes colonias de coral como consecuencia de la erosión, acompañado por la producción de sedimentos lodosos. A su vez, el crecimiento de las esponjas perforadoras y bioerosionadoras puede potenciarse por incrementos en la materia orgánica disponible y por las altas temperaturas (Rützler, 2004), condiciones que también son sumamente estresantes para los corales y que fueron observadas dentro de Perezoso.

\section{CONCLUSIONES}

El número de especies de esponjas marinas en el Caribe costarricense sobrepasa las 80, con 13 nuevos registros en este estudio. Las densidades, abundancias y coberturas relativas de las esponjas encontradas son un insumo importante para comprender la dinámica de los parches arrecifales y sus similitudes, así como las posibles presiones naturales y antropogénicas que contribuyen a moldearlos. El uso de índices ecológicos son herramientas que pueden ayudar a inferir el nivel de perturbación al que están expuestas las comunidades de esponjas, siempre que se interpreten con cautela y se contrasten con factores fisicoquímicos del entorno. Se recomienda probar y ajustar el diagrama para la valoración del grado de severidad y de pronosticabilidad ambiental según el área geográfica donde se quiera implementar.

La profundidad del arrecife pareció influir en la riqueza de especies de esponjas presentes, con aumentos en el número de especies conforme aumenta la profundidad. Por su lado, las tasas de sedimentación no mostraron tener un efecto en la similitud entre las comunidades de esponjas, pero el origen y la composición de dichos sedimentos sí podría estar influyendo en la cobertura de los poríferos, la abundancia de especialistas como $C$. venosa y la dominancia de esponjas resistentes al sedimento y a la turbidez como have very aggressive growths and considerable damage to the reefs when their abundance and coverage are high. For example, the excavation caused by these sponges can cause the breakage of large coral colonies as a consequence of erosion, accompanied by the production of muddy sediments. In turn, the growth of boring and bio-eroding sponges can be enhanced by increases in available organic matter and by high temperatures (Rützler, 2004), conditions that are also extremely stressful for corals and were observed within Perezoso.

\section{CONCLUSIONS}

The number of species of sea sponges in the Costa Rican Caribbean exceeds 80, with 13 new records in this study. The densities, abundance, and relative coverage of the sponges found are an important input in understanding the dynamics of the reef patches and their similarities, as well as the possible natural and anthropogenic pressures that contribute to shaping them. The use of ecological indices are tools that can help infer the level of disturbance to which sponge communities are exposed, provided they are interpreted cautiously and contrasted with physical and chemical factors in the environment. It is recommended to test and adjust the diagram to assess the degree of environmental severity and predictability according to the geographic area where you want to implement it.

The depth of the reef seemed to influence the species richness of sponges present, with increases in the number of species as depth increased. On the other hand, sedimentation rates did not show an effect on the similarity between sponge communities, but the origin and composition of these sediments could be influencing the coverage of poriferans, the abundance of specialists such as $C$. venosa and the dominance of sponges' resistant to sediment and turbidity such as $N$. erecta. Only the high percentages of bare calcareous pavement as the predominantly available substrate could explain the similarity between the Perezoso community structure and Coral Garden. This seemed to favour the abundance of heterotrophic and generalist sponges $N$. erecta, I. birotulata and $S$. ruetzleri, as well as the occurrence frequency of sponges of the genus Siphonodictyon and coverage of those of the genus Cliona. Furthermore, the evaluation of the occurrence frequency and the coverage of these two genera indicated that these sponges could be causing negative effects for the stony corals of Perezoso due to 
$N$. erecta. Sólo los altos porcentajes de pavimento calcáreo desnudo como sustrato disponible predominante pudieron explicar la similitud entre la estructura comunitaria de Perezoso y Coral Garden. Esto pareció favorecer la abundancia de las esponjas heterótrofas y generalistas $N$. erecta, I. birotulata y S. ruetzleri, así como la frecuencia de aparición de las esponjas del género Siphonodictyon y de la cobertura de las del género Cliona. Además, la evaluación de la frecuencia de aparición y la cobertura de estos dos géneros indicaron que dichas esponjas podrían estar causando efectos negativos para los corales pétreos de Perezoso debido a la bioerosión. El uso de esta información contribuirá a la selección de arrecifes donde sea más urgente tomar medidas de mitigación, e incluso, aquellos con potencialidades para desarrollar proyectos de restauración. Aunque este estudio amplía el entendimiento de la estructura comunitaria de las esponjas marinas en el Caribe de Costa Rica, se recomienda realizar más investigaciones en este campo y determinar si hay otros factores, tanto bióticos (disponibilidad de alimento, depredación, competencia) como abióticos (movimiento del agua, corrientes locales, turbidez, rugosidad del fondo), que pudieran influenciar en mayor medida en la estructura comunitaria de los poríferos. bioerosion. The use of this information will contribute to the selection of reefs where it is most urgent to take mitigation measures, and even those with the potential to develop restoration projects. Although this study broadens the understanding of the community structure of sea sponges in the Costa Rica Caribbean, it is recommended to carry out more research in this field and determine if there are other factors, both biotic (food availability, predation, competition) and abiotic (water movement, local currents, turbidity, roughness of the bottom), which could influence to a greater extent the community structure of the poriferans.

\section{ACKNOWLEDGEMENT}

To the members, assistants, and collaborators of the Project "Environmental indicators in marine and coastal ecosystems for the definition of conservation and management strategies in two protected areas in the South Caribbean of Costa Rica", to the Institute of Oceanology (current Institute of Marine Sciences) from Cuba, to Dr. Ricardo Jiménez Montealegre; as well as Don Manuel, Rafa, Ettel and the officials of the La Amistad-Caribe Conservation Area.

\section{AGRADECIMIENTOS}

A los miembros, asistentes y colaboradores del Proyecto "Indicadores ambientales en ecosistemas marinos y costeros para la definición de estrategias de conservación y manejo en dos áreas protegidas en el Caribe sur de Costa Rica”, al Instituto de Oceanología (actual Instituto de Ciencias el Mar) de Cuba, al Dr. Ricardo Jiménez Montealegre; así como a don Manuel, Rafa, Ettel y a los funcionarios del Área de Conservación La Amistad-Caribe.

\section{BIBLIOGRAFÍA/LITERATURE CITED}

Alcolado, P.M. 1999. Comunidades de esponjas de los arrecifes del archipiélago Sabana-Camagüey, Cuba. Bol. Invest. Mar. Cost., 28: 95-124.

Alcolado, P.M. 2002. Catálogo de las esponjas de Cuba. Avicenia, 15: 53-72.

Alcolado, P.M. 2007. Reading the code of coral reef sponge community composition and structure for environmental bio-monitoring: some experiences from Cuba: 3-10. En: Custódio, M.R., G. Lôbo-Hajdu, E. Hajdu y G. Muricy (Eds.), Porifera research: biodiversity, innovation and sustainability. Museu Nacional, Rio de Janeiro. 684 p.

Anderson, M.J., R.N. Gorley and K.R. Clarke. 2008. Permanova for Primer: guide to software and statistical methods. Primer-E Ltd, Plymouth, UK. 214 p. Bell, J.J. 2008. The functional roles of marine sponges. Estuar. Coast. Shelf Sci., 79: 341-353.

Bell, J.J., E. McGrath, A. Biggerstaff, T. Bates, H. Bennett, J. Marlow and M. Shaffer. 2015. Sediment impacts on marine sponges. Mar. Pollut. Bull., 94: 5-13. https://doi.org/10.1016/j.marpolbul.2015.03.030

Boury-Esnault, N. and K. Rüztler. 1997. Thesaurus of sponge morphology. Smithsonian Institution Press, Washington D.C. 55 p. 
Busutil, L. y P. Alcolado. 2012. Prueba de un índice de contaminación orgánica urbana basado en comunidades de esponjas de arrecifes de Cuba. Serie Oceanológica, 10: 90-103.

Caballero, H., L. Busutil, Y. García y P.M. Alcolado. 2009. Variación espacial en comunidades de esponjas de la costa oriental de bahía de Cochinos, Cuba. Rev. Mar. Cost., 1: 95-109.

Carballo, J.L., P. Gómez y J.A. Cruz-Barraza. 2014. Biodiversidad de Porifera en México. Rev. Mex. Biodiv., 85: 143-153. https://doi.org/10.7550/rmb.32074

Caribbean Coastal Marine Productivity (CARICOMP). 2001. Manual of methods for mapping and monitoring of physical and biological parameters in the coastal zone of the Caribbean. CARICOMP Data Management Center, Kingston.

Cedro, V.R., E. Hajdu, H.H. Sovierzosky and M. Dorigo. 2007. Demospongia (Porifera) of the shallow coral reefs of Maceió, Alagoas State, Brazil: $233-237$. En: Custódio, M.R., G. Lôbo-Hajdu, E. Hajdu y G. Muricy (Eds.). Porifera research: biodiversity, innovation and sustainability. Museu Nacional, Rio de Janeiro. 684 p.

Collin, R., M.C. Díaz, J. Norenburg, R.M. Rocha, J.A. Sánchez, A. Schulze, M. Schwartz and A. Valdés. 2005. Photographic identification guide to some common marine invertebrates of Bocas del Toro, Panama. Caribb. J. Sci., 3: 638-707.

Cortés, J. 1981. The coral reef at Cahuita, Costa Rica, a reef under stress. Tesis M. Sc. Univ. McMaster, Hamilton, Ontario, Canadá. 176 p.

Cortés, J. 1994. A reef under siltation stress: a decade of degradation: 240-246. In: Guinsburg, R.N. (compilador), Proc. Coll. Global Aspects Coral Reefs: Health, Hazards History. Univ. Miami. 420 p.

Cortés, J. 1996. Biodiversidad marina de Costa Rica: Filo Porifera. Rev. Biol. Trop., 44(2): 911-914.

Cortés, J. and C. Jiménez. 2003. Past, present and future of the coral reefs of the Caribbean coast of Costa Rica: 223-239. En: Cortés, J. (Ed.). Latin American coral reefs. Elsevier, Ámsterdam, Amsterdam. 508 p.

Cortés, J. and I.S. Wehrtmann, 2009. Diversity of marine habitats of the Caribbean and Pacific of Costa Rica: 1-45. In: Wehrtmann, I. S. y J. Cortés (Eds.). Marine biodiversity of Costa Rica, Central America. Springer, Berlín. 538 p.

Cortés, J. y M. Risk. 1984. El arrecife coralino del Parque Nacional Cahuita. Rev. Biol. Trop., 32: 109-121.

Cortés, J., A.C. Fonseca, J. Nivia-Ruiz and V. Nielsen-Muñoz. 2010. Monitoring coral reefs, seagrasses and mangrooves in Costa Rica (CARICOMP). Rev. Biol. Trop., 58(3): 1-22.

Cortés, J., N. Van Der Hal and R.W.M. Van Soest. 2009. Sponges: 137-142. In: Wehrtmann, I. S. y J. Cortés (Eds.). Marine biodiversity of Costa Rica, Central America. Springer, Berlín. 538 p.

Cortés, J., R. Soto, C. Jiménez and A. Astorga. 1992. Earthquake associated mortality of intertidal and coral reef organisms (Caribbean of Costa Rica). Proc. 7th Int. Coral Reef Symp., Guam, 1: 235-240.

Cruz-Barraza, J.A., J.L. Carballo, A. Rocha-Olivares, H. Ehrlich and M. Hog. 2012. Integrative taxonomy and molecular phylogeny of genus Aplysina (Demospongiae: Verongida) from Mexican Pacific. PLoS ONE, 7(8): e42049. https://doi.org/10.1371/journal.pone.0042049

Díaz, M.C. 2005. Common sponges from shallow marine habitats from Bocas del Toro Region, Panama. Caribb. J. Sci., 41(3): 365-375.

Díaz, M.C. 2012. Mangrove and coral reef sponge faunas: untold stories about shallow water Porifera in the Caribbean. Hydrobiologia, 687: 179-190. https:// doi.org/10.1007/s10750-011-0952-5

Díaz, M.C. and K. Rützler. 2001. Sponges: an essential component of Caribbean coral reefs. Bull. Mar. Sci., 69(2): 535-546.

Fonseca, A.C. 2003. A rapid assessment at Cahuita National Park, Costa Rica, 1999 (Part 1: Stony corals and algae). Atoll Res. Bull., 496: 248-257. https:// doi.org/10.5479/si.00775630.13.248

Garzón-Ferreira, J., M.C. Reyes-Nivia y A. Rodríguez-Ramírez. 2002. Manual de métodos del Sistema Nacional de Monitoreo de Arrecifes Coralinos en Colombia. INVEMAR, Santa Marta. $57 \mathrm{p}$.

Gochfeld, D.J., C. Schlöder and R.W. Thacker. 2007. Sponge community structure and disease prevalence on coral reefs in Bocas del Toro, Panama: 335 343. En: Custódio, M.R., G. Lôbo-Hajdu, E. Hajdu y G. Muricy (Eds.), Porifera research: biodiversity, innovation and sustainability. Museu Nacional, Rio de Janeiro. $684 \mathrm{p}$.

Hofman, C.C. and M. Kielman. 1992. The excavating sponges of the Santa Marta area, Colombia, with description of a new species. Bijdrajen tot de Dierkunde, 61(4): 205-2017.

Hooper, J.N.A. and R.W.M. Van Soest, 2002. Systema Porifera. A guide to the classification of sponges. Springer, New York. 1707 p. https://doi. org/10.1007/978-1-4615-0747-5_1

Hubbard, R.H. 1990. A sessile shallow-water community dominated by sponges and algae at Nelson island, Trinidad and Tobago. Caribb. Mar. Stud., 1(2): 152-158.

Loaiza, B. 1989. Generalidades del Phylum Porifera y bases para su identificación con sinopsis de algunas de ellas, en Limón, Costa Rica. Tesis Lic. Univ. Nacional, Heredia, Costa Rica. 173 p.

Loaiza, B. 1991. Estudio taxonómico de las esponjas del Parque Nacional Cahuita, sector Puerto Vargas e isla Uvita, Limón, Costa Rica. Brenesia, 36: $21-62$. 
López-Victoria, M. and S. Zea. 2005. Current trends of space occupation by encrusting excavating sponges on Colombian coral reefs. Mar. Ecol., 26: 33-41. https://doi.org/10.1111/j.1439-0485.2005.00036.x

Morrow, C. and P. Cárdenas. 2015. Proposal for a revised classification of the Demospongiae (Porifera). Front. Zool., 12(7). https://doi.org/10.1186/s12983015-0099-8

Núñez, M., J. G. Rodríguez-Quintal y M. C. Díaz. 2010. Distribución de esponjas (Porifera) a lo largo de un gradiente de profundidad en un arrecife coralino, Parque Nacional San Esteban, Carabobo, Venezuela. Rev. Biol. Trop., 58(3): 175-187.

Pielou, E.C. 1969. An introduction to mathematical ecology. Wiley-Interscience, New York. 292 p.

Risk, M.J., M. Murillo y J. Cortés, J. 1980. Observaciones biológicas preliminares sobre el arrecife coralino en el Parque Nacional Cahuita, Costa Rica. Rev. Biol. Trop., 28(2): 361-382.

Romero, M.A., E. Villamizar y N. Malaver. 2013. Estructura de las comunidades de esponjas (Porifera) en tres arrecifes del Parque Nacional Morrocoy, Venezuela y su relación con algunas variables ambientales. Rev. Biol. Trop., 61(3): 1229-1241. https://doi.org/10.15517/rbt.v61i3.11937

Rützler, K. 2004. Sponges on coral reefs: a community shaped by competitive cooperation. Boll. Mus. Ist. Biol. Univ. Genova, 68: 85-148.

Rützler, K., M.C. Díaz, R.W.M. Van Soest, S. Zea, K.P. Smith, B. Álvarez and J. Wulff. 2000. Diversity of sponge fauna in mangrove ponds, Pelican Cays, Belize. Atoll. Res. Bull., 476: 229-248. https://doi.org/10.5479/si.00775630.467.229

Shannon, C.E. 1948. A mathematical theory of communication. Bell Syst. Tech. J., 27: 379-423, 623-656. https://doi.org/10.1002/j.1538-7305.1948. tb01338.x

Simpson, E.H. 1949. Measurement of diversity. Nature, 163: 688-688. https://doi.org/10.1038/163688a0

Valderrama, D. and S. Zea. 2013. Annotated checklist of sponges (Porifera) from the southernmost Caribbean reefs (North-West Gulf of Urabá), with description of new records for the Colombian Caribbean. Rev. Acad. Colomb. Cienc., 37(144): 353-378.

Valderrama, D. y S. Zea. 2003. Esquemas de distribución de esponjas arrecifales (Porifera) del noroccidente del golfo de Urabá, Caribe sur, Colombia. Bol. Invest. Mar. Cost.: 32, 37-56.

Van der Hal, N. 2006. Presence and diversity of sponge species along the Caribbean coast of Costa Rica. Thesis Ámsterdam. 43 p.

Weinberg, S. 1981. A comparison of coral reef survey methods. Bijdr. Dierk., 51: 199-218.

Wulff, J.L. 2006. Ecological interactions of marine sponges. Can. J. Zool., 84: 146-166.

Wulff, J.L. 2012. Ecological interactions and the distribution, abundance, and diversity of sponges: 273-344. In: Becerro, M. A., M.J. Uriz, M. Maldonado y X. Turon (Eds). Advances in sponge science: phylogeny, systematics, ecology. Elsevier, UK. 450 p.

Zea, S. 1993. Cover of sponges and other sessile organisms in rocky and coral reef habitats of Santa Marta, Colombian Caribbean Sea. Caribb. J. Sci., 29(12): $75-88$.

Zea, S. 1994. Patterns of coral and sponge abundance in stressed coral reefs at Santa Marta, Colombian Caribbean. 257-264. En: Van Soest, R.W.M., T.M.G. Van Kempen y J.C. Braekman (Eds). Sponges in time and space: Biology, chemistry, paleontology. A.A. Balkema, Rotterdam, Países Bajos. 515 p.

Zea, S., T.P. Henkel and J.R. Pawlik. 2014. The sponge guide: a picture guide to Caribbean sponges (3era ed.). www.spongeguide.org. 03/11/2016

RECIBIDO/RECEIVED: 12/03/2019

ACEPTADO/ACCEPTED: 10/01/2020

\section{ANEXOS/ANNEXES}

Anexo 1. Clasificación taxonómica de las esponjas encontradas en el muestreo ("nuevos registros).

\section{Phylum Porifera}

Clase Demospongiae/Demospongiae class

Orden Agelasida/Agelasida order

Familia Agelasidae/Agelasidae family

Género Agelas/Agelas genus (Duchassaing y Michelotti, 1864)

Agelas schmidti* (Wilson, 1902)

Familia Hymerhabdiidae/Hymerhabdiidae family

Género Prosuberites/Prosuberites genus (Topsent, 1893)

Prosuberites laughlini (Díaz, Alvarez y van Soest, 1987) 
Orden Axinellida/Axinellida order

Familia Axinellidae/Axinellidae family

Género Dragmacidon/Dragmacidon genus (Hallmann, 1917)

Dragmacidon lunaecharta* (Ridley y Dendy, 1886)

Dragmacidon reticulatum (Ridley y Dendy, 1886)

Familia Raspaliinae/Raspaliinae family

Género Ectyoplasia/Ectyoplasia genus (Topsent, 1931)

Ectyoplasia ferox (Duchassaing y Michelotti, 1864)

Orden Chondrillida/Chondrillida order

Familia Halisarcidae/Halisarcidae family

Género Halisarca/Halisarca genus (Johnston, 1842)

Halisarca caerulea (Vacelet y Donadey, 1987)

Orden Clionaida/Clionaida order

Familia Clionidae/Clionidae family

Género Cliona/Cliona genus (Grant, 1826)

Cliona caribbaea (Carter, 1882)

Familia Placospongiidae/Placospongiidae family

Género Placospongia/Placospongia genus (Gray, 1867)

Placospongia intermedia (Sollas, 1888)

Familia Spirastrellidae/Spirastrellidae family

Género Spirastrella/Spirastrella genus (Schmidt, 1868)

Spirastrella coccinea (Duchassaing y Michelotti, 1864)

Orden Dictyoceratida/Dictyoceratida order

Familia Irciniidae/Irciniidae family

Género Ircinia/Ircinia genus (Nardo, 1833)

Ircinia campana (Lamarck, 1814)

Ircinia felix (Duchassaing y Michelotti, 1864)

Orden Haplosclerida/Haplosclerida order

Familia Callyspongiidae/Callyspongiidae family

Género Callyspongia/Callyspongia genus (Duchassaing y Michelotti, 1864)

Callyspongia pallida* (Hechtel, 1965)

Callyspongia vaginalis (Lamarck, 1814)

Familia Chalinidae/Chalinidae family

Género Haliclona/Haliclona genus (Grant, 1841)

Haliclona caerulea (Hechtel, 1965)

Familia Niphatidae/Niphatidae family

Género Niphates/Niphates genus (Duchassaing y Michelotti, 1864)

Niphates erecta (Duchassaing y Michelotti, 1864)

Niphates sp.

Familia Petrosiidae/Petrosiidae family

Género Neopetrosia/Neopetrosia genus (Laubenfels, 1949)

Neopetrosia proxima* (Duchassaing y Michelotti, 1864)

Género Petrosia/Petrosia genus Vosmaer, 1885

Petrosia pellasarca (Laubenfels, 1934)

Género Xestospongia/Xestospongia genus (Laubenfels, 1932)

Xestospongia muta (Schmidt, 1870)

Familia Phloeodictyidae/Phloeodictyidae family

Género Siphonodictyon/Siphonodictyon genus (Bergquist, 1965)

Siphonodictyon brevitubulatum (Pang, 1973)

Siphonodictyon coralliphagum (Rützler, 1971)

Siphonodictyon xamaycaense* (Pulitzer-Finali, 1986) 
Orden Poecillosclerida/Poecillosclerida order

Familia Crambeidae/Crambeidae family

Género Monanchora/Monanchora genus (Carter, 1883)

Monanchora arbuscula (Duchassaing y Michelotti, 1864)

Familia Iotrochotida/Iotrochotida family

Género Iotrochota/Iotrochota genus (Ridley, 1884)

Iotrochota birotulata (Higgin, 1877)

Familia Microcionidae/Microcionidae family

Género Clathria/Clathria genus (Schmidt, 1862)

Clathria curacaoensis (Arndt, 1927)

Clathria echinata* (Alcolado, 1984)

Clathria venosa (Alcolado, 1984)

Familia Mycalidae/Mycalidae family

Género Mycale/Mycale genus (Gray, 1867)

Mycale laevis (Carter, 1882)

Mycale microsigmatosa (Arndt, 1927)

Orden Scopalinida/Scopalinida order

Familia Scopalinidae/Scopalinidae family

Género Scopalina/Scopalina genus (Schmidt, 1862)

Scopalina ruetzleri (Wiedenmayer, 1977)

Género Svenzea/Svenzea genus (Álvarez, van Soest y Rützler, 2002)

Svenzea zeai* (Álvarez, van Soest y Rützler, 1998)

Orden Tetractinellida/Tetractinellida order

Familia Tetillidae/Tetillidae family

Género Cinachyrella/Cinachyrella genus (Wilson, 1925)

Cinachyrella alloclada (Uliczka, 1929)

Cinachyrella apion* (Uliczka, 1929)

Cinachyrella kuekenthali* (Uliczka, 1929)

Orden Verongiida/Verongiida order

Familia Aplysinidae/Aplysinidae family

Género Aiolochroia/Aiolochroia genus (Wiedenmayer, 1977)

Aiolochroia crassa (Hyatt, 1875)

Orden Verongiida/Verongiida order

Familia Aplysinidae/Aplysinidae family

Género Aplysina/Aplysina genus (Nardo, 1834)

Aplysina cauliformis (Carter, 1882)

Aplysina insularis (Duchassaing y Michelotti, 1864)

Aplysina lacunosa* (Lamarck, 1814)

Aplysina sp.

Género Verongula/Verongula genus (Verrill, 1907)

Verongula rígida (Esper, 1794)

Clase Homoscleromorpha/Homoscleromorpha class

Orden Homosclerophorida/Homosclerophorida order

Familia Plakinidae/Plakinidae family

Género Plakinastrella/Plakinastrella genus (Schulze, 1880)

Plakinastrella onkodes* (Uliczka, 1929)

Género Plakortis/Plakortis genus (Schulze, 1880)

Plakortis angulospiculatus* (Carter, 1879)

Plakortis sp. 